\title{
Impact of in situ stress and fault reactivation on seal integrity in the East Irish Sea Basin, UK
}

\author{
J.D.O. Williams ${ }^{1 *}$, C.M.A. Gent ${ }^{1}$, M.W. Fellgett ${ }^{1} \&$ D. Gamboa ${ }^{2}$ \\ ${ }^{1}$ British Geological Survey, Environmental Science Centre, Keyworth, Nottingham, NG12 5GG, UK \\ ${ }^{2}$ British Geological Survey, Cardiff University, Main Building, Park Place, Cardiff, CF10 3AT, UK \\ *Correspondence (jdow@bgs.ac.uk).
}

ORCiD of corresponding author: orcid.org/0000-0003-0177-9848.

\begin{abstract}
Despite having been affected by several stages of exhumation during the Cretaceous and Cenozoic, the contemporary stress state of the East Irish Sea (EISB) is poorly characterised. As the basin is mature in terms of exploitation of hydrocarbons, future exploration beyond the conventional Sherwood Sandstone Group reservoir (Triassic) necessitates a greater understanding of the in situ stress field, while proposed natural gas storage and carbon sequestration schemes also require detailed stress field information. Using petroleum well data, the in situ stress field of the EISB has been characterised to assess the mechanical seal integrity. A strike-slip stress regime most-likely prevails in the basin, meaning the Maximum Horizontal Stress $\left(S_{\text {Hmax }}\right)$ is the greatest of the principal stresses. Interpretation of stress orientation data suggests that $S_{H \max }$ is oriented $152^{\circ} \pm 12^{\circ}$, consistent with mean stress orientations across the wider region associated with plate boundary forces. Some degree of structural control appears to influence the orientation of $S_{\text {Hmax }}$, with orientations locally aligned sub-parallel to major Permo-Triassic basin-bounding faults.
\end{abstract}

Fault reactivation risk is evaluated through modelling the pore pressure increase required to induce failure on pre-existing faults. Vertical faults striking $30^{\circ}$ from $S_{H \max }$ are optimally-oriented to become reactivated under elevated pore pressure conditions. For any project relying on an element of fault seal for the containment of buoyant fluids at the average reservoir depth of $800 \mathrm{~m}$, pore pressure increase should be less than 3.3 MPa to avoid reactivating pre-existing optimally-oriented faults. Higher pressure increases would be required to initiate reactivation of faults with other orientations. Vertical faults striking perpendicular to $S_{\text {Hmax }}$ are least likely to become reactivated, and in the absence of halite, seal integrity would instead be limited by caprock strength and capillary-entry pressure.

Major faults affecting the basin have been analysed for their slip tendency (ratio of shear to normal stress), which provides an indication of their susceptibility to become reactivated. Although the analysis is limited due to lack of an accurate 3D representation of the fault network, the results suggest that many of the fault orientations observed in the EISB exhibit high slip tendencies, including N-S striking faults to the north and west of the East Deemster Fault, where the $S_{\text {Hmax }}$ orientation is NW-SE. Faults striking perpendicular to $S_{\text {Hmax }}$, such as the Lagman Fault, are least likely to become reactivated due to higher normal stresses that inhibit frictional sliding, while faults striking parallel or very close to $S_{H \max }$ also exhibit low slip tendency as they are not subjected to significant shear stresses.

END 
Keywords: Horizontal stress; fracture pressure; Mercia Mudstone; Sherwood Sandstone; pore pressure; stress field; exhumation; caprock integrity 


\section{Introduction}

Accurate determination of the effective in situ stress conditions is critical for effectively managing subsurface resources, particularly in mature hydrocarbon provinces such as the East Irish Sea Basin (EISB). Characterisation of the in situ stress state is essential for a range of subsurface engineering and energy applications (Bell 1996; Hillis \& Nelson 2005; Tingay et al. 2005), including seal integrity studies relating to exploration and storage of hydrocarbons (Wiprut \& Zoback 2000; Finkbeiner et al. 2001; Reynolds et al. 2003; Meng et al. 2017), and carbon capture and storage (Lucier et al. 2006; Chiaramonte et al. 2008; Williams et al. 2016). Detailed stress field information is also commonly applied to the study of fluid flow through or along faults, as faults can constitute a risk to hydrocarbon exploration and subsurface fluid storage while also contributing positively to flow in tight, unconventional or geothermal reservoirs (Barton et al. 1995; Bjørlykke et al. 2005; Mildren et al. 2005; Bretan et al. 2011; Hennings et al. 2012).

Located in the heart of the UK with restricted outlets to the Atlantic Ocean, the EISB is surrounded by Ireland, Scotland, NW England and Wales (Figure 1). Hydrocarbon exploration began in earnest in 1969 with the drilling of the 110/08-1 well and the later discovery of the South Morecambe Gas Field in 1974 (Colter 1997; Bastin et al. 2003). Production to date has been exclusively from the Triassic, with a Sherwood Sandstone Group reservoir capped by the Mercia Mudstone Group (Figure 2). Aside from untested structures associated with this conventional petroleum system, future exploration might focus on prospective Palaeozoic targets such as the potential Carboniferous plays recently identified by Pharaoh et al. (2016; in press). The EISB is also of interest in terms of its potential for carbon capture and storage (Armitage et al. 2013; Lewis et al. 2009), whereby emissions are captured from anthropogenic sources such as power plants, and injected to subsurface reservoirs for long-term storage. In addition, the EISB also offers the potential for natural gas storage, both in porous sandstones and in solution-mined salt caverns (Evans \& Holloway 2009). Relative to conventional exploration and production activities, these undertakings will require a greater understanding of the in situ stress field.

Despite the long history of hydrocarbon development in the EISB there is a paucity of publically available data relating to the in situ stress conditions, and no stress orientation data are included in recent editions of the World Stress Map (Heidbach et al. 2008; 2010; 2016). A complex history of vertical movement, compressional deformation and inversion has affected the EISB (Cowan et al. 1999; Quirk et al. 1999), and so understanding the current state of stress and its controlling factors is important for any application where geomechanical characterisation is required. The large volume of well data available from the legacy of exploration and production are used here to characterise the in situ stress conditions and their variations across the EISB, and to examine the implications for seal integrity in the region.

\section{Geological Setting}

The post-Variscan basin of the East Irish Sea is one of the largest and deepest post-Carboniferous depocentres of Western Britain (Jackson et al. 1995). Its present form (Figure 1) was generated by E-W to NW-SE extension associated with Permian-Triassic rifting events, resulting in a series of N-S striking grabens and structural highs (Chadwick et al. 1994; Jackson et al. 1995; Jackson \& Mulholland 1993; Needham \& Morgan 1997). Two main structural domains are recognised, strictly related to the presence of late Permian evaporite. A southern, densely faulted domain is dominated by $\mathrm{N}-\mathrm{S}$ striking faults, while a northern domain is dominated by westerly tilted half grabens influenced by low-angle listric faults detached along Upper Permian evaporites (Jackson \& Mulholland 1993).

Hydrocarbons were generated principally by organic-rich marine mudstones of Carboniferous age (Cowan et al. 1999; Jackson et al. 1995; Pharaoh et al. 2016). The Carboniferous strata were deposited in basins associated with NNW-SSE extension, later folded along reactivated WSW-ENE Caledonian structures during the Variscan Orogeny. Carboniferous strata underlie much of the EISB, but subcrop 
beneath Quaternary sediments to the west (Jackson et al. 1995). The top of the Carboniferous is marked by a regional angular unconformity over which continental sandstones of the Lower Permian Collyhurst Sandstone Formation (Figure 2) were deposited in narrow half-grabens. Upper Permian marine incursions resulted in sedimentation styles characteristic of coastal sabkhas, while halites and anhydrites of the St Bees Evaporite Formation were deposited in the central parts of the EISB. Towards the south, Upper Permian strata thins and abruptly transitions to mudstones and dolomitic siltstones of the Manchester Marls Formation. Increased thicknesses of Permian strata in the hangingwalls of some faults provides evidence of syn-sedimentary fault movement, although overall subsidence rates were limited at this time (Jackson et al. 1995).

The principal hydrocarbon-bearing reservoir in the basin is the Lower Triassic Sherwood Sandstone Group (SSG), which marks the onset of Triassic deposition during a period of increased tectonic activity associated with North Atlantic rifting and rapid basin subsidence. Syn-tectonic deposition in NNWSSE oriented basins and thickening towards large growth-faults is observed (Jackson \& Mulholland 1993; Knipe et al. 1993). Sediments were deposited in a predominantly fluvial environment with ephemeral playa influences, and increasingly aeolian deposition towards the top (Jackson et al. 1995). In the EISB the SSG is divided into two formations, the St Bees and Ormskirk Sandstone Formations. The earliest of these, the St. Bees Sandstone Formation, rests unconformably over Permian strata, with a sharp contact to the south over the Manchester Marls Formation (Figure 2). The St Bees Formation is on average $1200 \mathrm{~m}$ thick, with recorded thicknesses of $1700 \mathrm{~m}$ adjacent to the Lake District Boundary Fault, however it thins southwards to about $900 \mathrm{~m}$ (Jackson et al. 1995). An abrupt transition associated with tectonic and/or climatic changes marks the onset of the Ormskirk Sandstone Formation (Cowan 1993; Stuart 1993). The Ormskirk Sandstone is on average $250 \mathrm{~m}$ thick, but constitutes the most economically important interval in the region, as it forms the reservoir to the majority of hydrocarbon discoveries. The Ormskirk Sandstone is composed of cleaner thickly-bedded sandstones with an increase in aeolian sandstone content contrasting with the finer-grained argillaceous and fluvialdominated facies of the underlying St Bees Sandstone.

The Mercia Mudstone Group (MMG) forms the main caprock in the conventional EISB petroleum system, comprising of alternating mudstones, anhydrites, siltstones, dolomites and evaporites deposited during the Late Triassic. The preserved thickness of MMG is highly variable, being significantly thinned or absent due to erosion, however $3200 \mathrm{~m}$ of MMG are preserved in the Keys Basin, part of the northern structural domain. The distribution of halite members within the EISB are illustrated by Jackson et al. (1995), and their thickness is controlled in part by faulting and areas of high subsidence, resulting in highly variable thickness distributions. Numerous low-angle listric faults, glide planes and halokinetic structures associated with the Rossall Halite Member are clearly identified in the MMG (Jackson et al. 1995; Jackson \& Mulholland 1993; Wilson 1990).

With the exception of $600 \mathrm{~m}$ of Jurassic strata in the hangingwall of the Keys Fault, post-Triassic strata are virtually absent due to erosion associated with regional uplift and basin inversion (Chadwick et al. 1994; Hillis et al. 2008; Holford et al. 2005; Holford et al. 2009). Apatite fission track, vitrinite reflectance and sonic log analyses indicate phased regional uplift episodes distributed in three main inversion phases as a result of major plate-scale reorganisations, with magnitudes decreasing over time (Holford et al. 2005). The main phase of exhumation (2-3 km) took place during the early Cretaceous and is likely associated with Atlantic rifting events, with an estimated onset between $120 \mathrm{Ma}$ and 115 Ma (Hillis et al. 2008; Holford et al. 2005). The early Palaeogene exhumation mechanism for the EISB remains debatable due to limited evidence of inversion structures for this period. Rowley \& White (1998) proposed isostatic response to underplating associated with emplacement of the Iceland Plume as a mechanism for Palaeogene exhumation, however later studies suggest that contractional reactivation of basin faults resulting from Alpine convergence was responsible (Holford et al. 2008; Williams et al. 2005). A combination of tectonic inversion and crustal shortening with magmatism 
(associated with plume activity or North Atlantic break-up) is the likely mechanism that led to exhumation of about 1-2 km (Holford et al. 2005; Williams et al. 2005). An estimated $1 \mathrm{~km}$ of exhumation occurred in Oligo-Miocene times as a response to transpressional deformation along major NW trending faults (Holford et al. 2005; Turner 1997), although some inversion structures in the Irish Sea Basin may be of late Miocene age, and the result of late Alpine deformation (Blundell 2002). Total exhumation was not equally distributed within the EISB, with higher values being estimated in the southern peripheral areas relative to the deeper parts of the central Keys Basin (Holford et al. 2005). Significant localised variation in estimated exhumation occur over short distances across individual faults (Ware \& Turner 2002).

Trap development is estimated to have initiated by the Late Triassic, with fluid migration into the Ormskirk Sandstone as early as the early-mid Jurassic (Stuart \& Cowan 1991). Structural traps were created or enhanced as a result of the reactivation episodes, however the true identification of reverse structures is not always clear due to salt movement and significant extension of roll-over anticlines adjacent to listric faults (Chadwick et al. 1994). Considerable re-migration of hydrocarbons also occurred as a result of basin inversion (Cowan et al. 1999).

\section{Controls on Caprock Integrity}

In a study of caprock integrity in the EISB, Seedhouse \& Racey (1997) concluded that the lithology overlying the SSG is the most important factor affecting the seal integrity, with evaporites providing excellent seal integrity, while the seal capacity of mudstone lithologies is limited by their capillary entry pressure. The MMG locally comprises thin interbedded mudstones and siltstones, and some of the interstitial pore space is observed to be plugged by bitumen (Seedhouse \& Racey 1997). Hydrofractures generated as a result of overpressure during inversion, are also filled with bitumen, indicating that they once acted as conduits for liquid hydrocarbons. There is a positive correlation between the column heights of present-day hydrocarbon accumulations and depth to structure (Cowan et al. 1999), indicating that seal integrity is most likely to be maintained in deeper parts of the EISB, and is limited in shallow structures ( $<450 \mathrm{~m}$ depth), particularly where the overlying halite members are absent (Cowan et al. 1999). Mechanical compaction of mudrocks during burial results in smaller pore throat radii (Corcoran \& Doré 2002), while shales in the EISB exhibit higher capillary entry pressures than shales at equivalent depths in non-inverted basins (Cowan et al. 1999). For structures in the EISB that are not filled to spill, the principal control on seal integrity is therefore likely to have been hydrofracturing during uplift. Whilst re-migration of hydrocarbons and seal breach have been reported as a result of burial history and potentially during halokinesis associated with glacial unloading (Cowan et al. 1999), to the author's knowledge there is no evidence for current leakage of hydrocarbons from present-day traps. An evaluation of seismic reflection data to assess caprock continuity and fluid-flow anomalies such as bright-spots or gas chimneys could be undertaken to further assess present-day caprock integrity.

Permeability measurements of MMG core samples from onshore UK, indicate permeabilities as low as $1 \times 10^{-5} \mathrm{mD}$, indicating very high sealing capacity in clay (illite) rich samples (Armitage et al. 2015). Similarly, Spain \& Conrad (1997) present mercury-injection capillary-pressure results from equivalent strata in the Netherlands Sector of the North Sea, where permeabilities range from $0.0022-0.0165 \mathrm{mD}$, and gas-water capillary-entry pressures range from 0.4-9 MPa (Spain \& Conrad 1997). Despite the wide range in the capillary-seal capacity of the MMG, the presence of significant gas columns preserved in the EISB proves that present-day seal integrity of the MMG is maintained, despite the complex burial history and evidence for inversion-related breaching of the seal (Seedhouse \& Racey 1997; Cowan et al. 1999; Quirk et al. 1999). In an assessment of the mineralogy, petrology and mercury injection porosimetry, Armitage et al. (2013) concluded that the MMG probably represents a durable caprock for future carbon dioxide storage in the SSG. 
Williams et al. (2014) investigated seal integrity of correlative strata in the UK Southern North Sea, suggesting that under elevated pore pressures (resulting from simulated injection of carbon dioxide), the most likely mechanism for seal failure is the reactivation of pre-existing faults. The relationship between in situ stress and fluid flow in faults is well established, with critically stressed faults aligned favourably to the stress tensor perceived as being most likely to be hydraulically conductive and posing a greater risk to seal integrity. While this has been shown not to be true in all cases (Laubach et al. 2004; Sathar et al. 2012; Cuss et al. 2015), a number of studies from a variety of settings worldwide (Barton et al. 1995; Wiprut \& Zoback 2000; Finkbeiner et al. 2001; Hennings et al. 2012) indicate that it is useful to adopt as a general rule in assessing seal integrity, at least in the absence of evidence regarding specific fault properties. In a study of fluid flow in naturally occurring fractures at the Soultzsous-Forets Hot Dry Rock geothermal site in France, Evans (2005) showed that while all flowing fractures were observed to be critically stressed, a large number of similarly stressed fractures were not hydraulically conductive. The implication therefore, is that the criticality of faults provides a conservative assessment of their risk to seal integrity because not all critically stressed faults will necessarily promote seal bypass. The in situ stress field in the EISB is therefore evaluated in order to assess seal integrity risk in terms of the potential for fault reactivation.

\section{Methods}

Stress is a six component tensor that, at depth, can be resolved into three principal components (Zoback et al. 2003). The vertical stress $\left(S_{v}\right)$ is generally considered to be one of the three principal stresses in the subsurface, while the other two are horizontal and orthogonal to each other. In order to characterise the effective in situ stress field, knowledge of the pore pressure distribution and the orientation and magnitude of the three principal stresses are required. Such information can be derived from data commonly acquired in hydrocarbon wells.

In permeable formations, direct measurements of pore pressure at specific points along a borehole wall can be provided by Repeat Formation Tester (RFT), Modular Formation Dynamics Tester (MDT) and Formation Multi Tester (FMT) tools.

The orientation of the horizontal stresses can be characterised from borehole failure mechanisms resulting from stress concentration around wellbores once material supporting the surrounding rock is removed during drilling (Zoback et al. 1985; Bell 1990). Compressive and tensile failure result in borehole breakouts and drilling-induced tensile fractures, respectively. Drilling-induced tensile fractures develop as narrow features sub-parallel to the borehole axis in vertical wells, but do not result in significant borehole enlargement (Brudy \& Zoback 1999). In approximately vertical wells (deviation less than $10^{\circ}$ ) they strike in the direction of the Maximum Horizontal Stress $\left(S_{\text {Hmax }}\right)$ (Aadnoy \& Bell 1998). Conversely, borehole breakouts are enlargements of the borehole wall formed by the development of conjugate shear fractures. In approximately vertical wells the borehole is enlarged in the direction of the Minimum Horizontal Stress $\left(S_{h m i n}\right)$. Breakouts and drilling-induced tensile fractures can be observed using ultrasonic and electrical borehole image logs, including the Ultrasonic Borehole Imager (UBI), Formation Micro Scanner (FMS), Formation Micro Imager (FMI) and Circumferential Borehole Imaging (CMI) tools.

While the magnitude of $S_{v}$ can be estimated from the integration of bulk density logs (Zoback et al. 2003), the magnitude of the horizontal stresses is more difficult to constrain. The magnitude of the least principal stress, $S_{\text {hmin }}$ in normal and strike-slip stress regimes, is commonly estimated from leak-off tests (LOTs), during which small-scale hydraulic fracturing occurs. These pumping tests are conducted in short open-hole well sections often beneath cemented casing shoes, principally in order to assess drilling mud densities, however they are also useful for estimating the magnitude of the least principal stress. In regional compilations of in situ stress data, LOT data are plotted relative to depth, and a lower bound provides a reasonable estimate of the magnitude of the least principal stress (Breckels \& van Eekelen 1982; Addis et al. 1998). The magnitude of $S_{\text {Hmax }}$ is generally the most difficult parameter to constrain. 
The presence of drilling-induced tensile fractures and borehole breakouts can be useful in estimating the magnitude of $S_{\text {Hmax }}$ as particular conditions are required in order for them to form (Barton \& Zoback 1988; Moos \& Zoback 1990; Zoback et al. 2003.). This however requires accurate knowledge of the pore pressure and temperature during drilling, and of the tensile and compressive strength of the rock at the specific depths where the breakouts or drilling-induced tensile fractures are observed. In the absence of such data, broad limits can be placed on the magnitude of $S_{\text {Hmax }}$ based on frictional limits to stress, beyond which faulting would be expected to occur (Reynolds et al. 2003).

The methods above have been used to determine a regionally applicable in situ stress model which is used to assess the potential for fault reactivation in the EISB. When the full stress tensor is known, the potential of faults with any given orientation to become reactivated, as well as the pore pressure increase required to induce failure can be calculated (Ferrill et al. 1999; Reynolds et al. 2003). Such an increase in pore pressure can be induced by the continued accumulation of a hydrocarbon column asserting buoyancy pressure on the fault (Finkbeiner et al.2001), or from the injection of fluids such as natural gas for short-term storage or disposal of waste products such as $\mathrm{CO}_{2}$ (Chadwick et al. 2009; Meng et al. 2017).

\section{EISB in situ stress field}

\subsection{Pore Pressure}

Direct pressure measurements have been extracted from 77 hydrocarbon wells (Figure 3). The data are predominantly measured from intervals within the SSG, although one well (110/13-1) contains some measurements from the Permian Collyhurst Sandstone Formation. The pore pressure is generally characterised by a gradient of $11.628 \mathrm{MPa} / \mathrm{km}$, which is consistent in both the Triassic and Permian measurements. The data also display the many elevated pressures associated with buoyant hydrocarbon columns owing to the density contrast between hydrocarbons and formation brine. Some wells (most notably $110 / 02 \mathrm{a}-\mathrm{H} 9$ and $110 / 02 \mathrm{~b}-\mathrm{R} 3 \mathrm{Y}$ ), highlight pressure depletion effects due to hydrocarbon production (Figure 3). Hydraulic connectivity within the SSG saline aquifer, at least where it is not significantly offset by major faults, is demonstrated by pressure data from well 110/03b-6A which tested a structure $\sim 8 \mathrm{~km}$ to the east of the South Morecambe Field in 2009, with pressure depleted by several MPa. Differential pressure depletion effects over short depth intervals in some wells implies significant vertical heterogeneity, most clearly seen in well 113/27a-Q3 from the Millom Gas Field which is known to exhibit poor vertical permeability (Cowan \& Bradney 1997).

Wells in the Keys Basin, are somewhat underpressured by comparison with the rest of the EISB, by up to $\sim 1.2 \mathrm{MPa}$ (Figure 3). Swarbrick \& Osborne (1998) suggested the following mechanisms for the generation of underpressure:

- Hydrodynamic flow (differential discharge rates in topographically-driven flow systems).

- Rapid migration of exsolved gas from low permeability reservoirs during uplift relative to the rate of gas ingress.

- Dilation of pores in shallowly buried mudrocks due to removal of vertical load.

- Aquathermal contraction (fluid shrinkage during cooling).

- Osmotic flow across shale membranes separating formations with differing salinity.

Underpressured rocks are typically therefore found in exhumed basins, suggesting that underpressure is caused by volumetric pore and pore-fluid volume changes due to decreases in temperature and pressure, along with hydraulic realignment during exhumation (Corcoran \& Dóre 2002). The lower pressure observed in the Keys Basin likely reflects this variation in burial and uplift history.

\subsection{Vertical Stress}

The magnitude of the vertical stress $\left(S_{v}\right)$ at a specific depth can be equated to the pressure exerted by the weight of the overburden. It can be obtained by integrating bulk densities from the surface to the 
depth of interest $(z)$ according to equation 1 , or equation 2 in the case of offshore settings after Zoback et al. (2003):

$s_{V}=\int_{0}^{z} \rho(z) g d z \approx \bar{\rho} g z$

$s_{V}=\rho_{w} g z_{w}+\int_{z_{w}}^{z} \rho(z) g d z \approx \rho_{w} g z_{w}+\bar{\rho} g\left(z-z_{w}\right)$

Where $\rho(z)$ is density as a function of depth, $g$ is the acceleration due to gravity, $\bar{\rho}$ is the mean overburden density, $\rho_{w}$ is the density of water (taken as $1 \mathrm{~g} / \mathrm{cm}^{3}$ ) and $z_{w}$ is water depth. Bulk density logs from 35 wells across the EISB were integrated in order to derive the vertical stress. Density logs are not commonly acquired to surface and are commonly affected by bad hole conditions (and any cased intervals encountered by the tool), and so a quality control process was undertaken to clean and replace bad-hole sections, and to estimate the density values in missing log sections and to account for the varying height of the water column. The data are presented in Figure 4, and can be approximated for the basin as a whole using a power law function (equation 3). Variations in $S_{v}$ between individual wells are the results of variations in stratigraphy and burial history. The 110/03-2 well, which forms the lower bound to the $S_{v}$ envelope shown in Figure 4, is situated in the Crosh Vusta Graben where $>700 \mathrm{~m}$ of halite was deposited within the MMG, leading to reduced overburden densities. After the minimum denudation estimates modelled by Rowley \& White (1998), wells that form the upper bound to the $S_{v}$ data are those in areas that have been subjected to significant denudation, such as $112 / 25 \mathrm{a}-1$ in the hangingwall of the Lagman Fault, implying deeper burial prior to exhumation.

$s_{V}=0.0159 z^{1 \cdot 0511}$

\subsection{Horizontal Stress Orientations}

Although no data regarding the orientation of $S_{\text {Hmax }}$ in the EISB are available in current editions of the World Stress Map (Heidbach et al. 2008; 2010; 2016), several recent publications have analysed borehole breakouts and drilling-induced tensile fractures in order to assess the $S_{H \max }$ orientation in the UK and surrounding offshore regions. Assessment of the stress orientation of Central and Northern England (Kingdon et al. 2016), predominantly within the Carboniferous Coal Measures, found that $S_{\text {Hmax }}$ is orientated NW-SE $\left(150.9^{\circ}\right)$, with a standard deviation of $13.1^{\circ}$ suggesting little variation in the orientation of far-field stress. A similar orientation is found in offshore UK regions such as the Southern North Sea (Williams et al. 2015) and the Faroe-Shetland region (Holford et al. 2016), albeit with a degree of short-wavelength variation related to local structural features superimposed on the roughly NW-SE regional trend. The regional orientation is controlled principally by plate boundary forces, reflecting the configuration of plate boundaries and tectonic forces (Müller et al. 1992; Gölke \& Coblentz 1996). Variable orientations of $S_{\text {Hmax }}$ are seen in some parts of the UK Continental Shelf because thick Permian evaporites decouple the stress field in the post-Permian sedimentary succession from stresses affecting the basement rocks (Hillis \& Nelson 2005; Williams et al. 2015), or because structural features such as mechanically weak or active faults locally deflect stress orientations (Holford et al. 2016; Williams et al. 2016).

Analysis of image logs from approximately vertical sections in 12 wells in the EISB has identified reliable borehole stress indicators in six wells (Table 1). A typical example of a borehole breakout feature from well 109/05-1 is shown in Figure 5. When the orientations from all wells are aggregated, the data support an average $S_{H \max }$ orientation of $152^{\circ}$, consistent with the regional UK stress orientation. The calculated orientations have been subjected to the quality ranking scheme utilised by the World Stress Map (WSM) project (Sperner et al. 2003; Heidbach et al. 2010). Although it is important to note that the number of data available are relatively few, there appears to be a systematic variation in the orientation of $S_{\text {Hmax }}$ from N-S in the southerly part of the EISB, to NW-SE in the North (Figure 6), corresponding to the orientation of the dominant structural domains. The orientations appear to strike parallel or sub-parallel (up to $\sim 30^{\circ}$ ) to the orientation of the major structural features in the proximity 
of the well locations, implying that the major basin-bounding faults might locally be exerting some control on the orientation of $S_{H \max }$. Stress orientation data have also been identified for three recently released onshore wells bordering the EISB (Table 2), two of which have been interpreted as part of this study, and another (Preese Hall, the UK's first dedicated shale gas exploration well) interpreted by Baker Hughes (2011). The onshore wells show similar mean orientations to those offshore, while also showing some resemblance to the orientation of major Permo-Triassic structures (Figure 6). Given that the standard deviation is low (Table 1) when the orientations from all wells offshore are aggregated, the mean orientation of $152^{\circ}$ is considered to be a good representation of the far field stresses affecting the EISB.

\subsection{Horizontal Stress Magnitudes}

Leak-off test (LOT) data were extracted from company records for 89 wells across the EISB (Figure 7). Data were taken as recorded by the various companies, but the actual pumping pressure charts were unavailable for validation. Most of the data constitute Formation Integrity Tests (FITs) rather than true LOTs. These tests are where the pressure is not taken to leak-off. It is assumed that the notation on the company records follows this convention, so that LOTs are taken to fracture whereas FITs are not, however it is not possible to verify this without consulting the raw data which are not available. Hydraulic fracture tests and extended leak-off tests (XLOTs or ELOTs) provide improved estimates of the least principal stress magnitude (Addis et al. 1998; White et al. 2002), however no such data were available to this study. The data are presented in Figure 7, and suggest that the leak-off pressure commonly exceeds the magnitude of the vertical stress. LOT measurements depend on other factors in addition to stress magnitude, such as the lithology and rock strength at the depth tested, the properties of the drilling fluids, and wellbore stability. The data would suggest that the rocks present at the depths where the tests were conducted (principally within the MMG) possess an anomalously high strength relative to their present depth. Corcoran \& Doré (2002) discuss the impact of burial and exhumation on the tensile strength of claystones in exhumed Atlantic margin and borderland basins. Up to $2132 \mathrm{~m}$ of overburden has been denuded from over the preserved MMG (Ware \& Turner 2002), so the claystones have been subject to increased mechanical compaction at greater depths, contributing to high shear and tensile strength. As supported by the LOT data from the EISB, exhumed claystones retain strength commensurate to their maximum burial depth (Corcoran \& Doré 2002), and so higher pore-pressure is required to cause fracturing of the intact rock relative to claystones at similar present day depth in nonexhumed basins, as long as the exhumation occurred prior to embrittlement.

A gradient of $18 \mathrm{MPa} / \mathrm{km}$ provides a minimum bound to the LOT data which can be used to estimate the magnitude of the least principal stress $\left(S_{h m i n}\right)$ at depth in the absence of detailed XLOT/ELOT measurements. As the magnitude of the least principal stress is less than the vertical stress (Figure 7), a compressive stress regime $\left(S_{v}<S_{\text {hmin }}<S_{H \max }\right)$ can be discounted, and the stress state of the EISB must either be one of normal $\left(S_{h \min }<S_{H \max }<S_{v}\right)$ or strike-slip $\left(S_{\text {hmin }}<S_{v}<S_{H \max }\right)$ faulting. Earthquake focal mechanisms suggest a dominantly strike-slip state of stress over most of the onshore UK region, with the exception of dominantly compressional stresses north of the Midland Valley in Scotland (Baptie 2010). Given that the orientation of $S_{\text {Hmax }}$ in the EISB is consistent with onshore data, it is expected that a strike-slip stress state can also be expected in the EISB. As detailed data are unavailable to accurately constrain the magnitude of $S_{\text {Hmax }}$, frictional limits can be applied to provide an upper bound after Jaeger et al. (2007). This assumes that the differential stress, or ratio of the maximum to minimum effective stress magnitudes, cannot exceed a value required to cause reactivation of pre-existing faults preferentially-oriented with respect to the prevailing stress regime (equation 4):

$\frac{\sigma_{1}}{\sigma_{3}}=\frac{\mathrm{S} 1-P_{P}}{\mathrm{~S} 3-P_{P}} \leq\left[\left(\mu^{2}+1\right)^{1 / 2}+\mu\right]^{2}$

Where $\mathrm{S} 1$ and $\mathrm{S} 3$ are the maximum and minimum principal stresses respectively, $P p$ is the pore pressure, and $\mu$ is the coefficient of friction. After Byerlee (1978), $\mu$ is commonly $0.6 \leq \mu \leq 1$, so two values ( 0.6 and 0.4$)$ were selected to account for the potential range of frictional fault rock properties, 
within the range of fault gouge properties reported by Haines et al. (2014) and Ferrill et al. (2017). The value of $\mu$ is likely to vary depending on the clay content of the fault gouge, with clay-rich gouges having lower values of $\mu$ compared to clast-rich fault gouges (Haines et al. 2014). The estimated $S_{\text {Hmax }}$ gradient for $\mu=0.6$ is $31.54 \mathrm{MPa} / \mathrm{km}$, and for $\mu=0.4$ is $25.55 \mathrm{MPa} / \mathrm{km}$.

\subsection{Full stress tensor}

Although the precise magnitudes of the effective in situ stresses will vary between specific locations, the full stress tensor at depth for the EISB can be approximated using the data compiled in this study (Figure 8). Note that in the upper few hundred metres there is significant uncertainty regarding the pore pressure and stress magnitudes as the gradients converge towards the seabed, complicated by lateral variations in sea-water depth and by lack of data in the shallow subsurface.

\section{Risking Fault Reactivation and Seal Integrity}

Pre-existing faults that are subjected to stresses sufficient to induce failure commonly provide conduits allowing for fluid-flow through otherwise low permeability strata, leading to potential loss of seal integrity (Clayton \& Hay 1994; Sibson 1994; Barton et al. 1995; Dewhurst et al. 1999; Wiprut \& Zoback 2000; Finkbeiner et al. 2001). Conditions required to induce brittle failure can be predicted using a Mohr approach, whereby the Mohr circle representing the stress tensor is described alongside a failure envelope representing the frictional strength of the fault. Changes in pore pressure will affect the effective stresses, moving the position of the Mohr circle, with brittle failure occurring when the Mohr circle comes into contact with the failure envelope.

For pre-existing faults of any given orientation at specific depth, brittle failure theory can be used to determine the pore pressure perturbation $(\Delta P)$ that would result in fault reactivation (Mildren et al. 2005). The average depth to the top of the Ormskirk Sandstone Formation in the EISB is $\sim 800 \mathrm{~m}$, therefore the $\Delta P$ for faults has been calculated for that depth and are shown for two cases using stereographic projections (Figure 9) based on the parameters given in Table 3. Fault orientations with low $\Delta P$ values do not require significant increases in pore pressure to become reactivated, while faults with higher values require significant increases in pore pressure before they can be reactivated. Given the lack of rock failure envelopes for the region, two different cases are assumed with different values for $\mu$, while cohesion $(C)$ is given as $2 \mathrm{MPa}$ to account for fault rock strength.

Under the assumed strike-slip stress regime $\left(S_{h \min }<S_{v}<S_{H \max }\right)$, faults that are most likely to become reactivated under elevated pore pressures are vertical faults striking $30^{\circ}$ from $S_{H \max }$, at angles of $182^{\circ}$ or $122^{\circ}$. Such faults would require increases in pore pressure of $\sim 3.3$ or $5 \mathrm{MPa}$ for cases 1 and 2 respectively. In both cases, vertical faults striking parallel with $S_{h \min }\left(62^{\circ}\right)$ are least likely to become reactivated, requiring $\Delta P$ of over $15 \mathrm{MPa}$ in both cases. Case 2 shows less range in $\Delta P$ values than Case 1 , due to the lower differential stress which results in a smaller Mohr circle with greater distance from the failure envelope (Figure 10). For certain non-optimally oriented fault orientations, the pore pressure required to initiate fault reactivation exceeds the least principal stress magnitude $\left(S_{h m i n}\right)$, in which case new hydrofractures would be expected to form prior to fault reactivation.

To illustrate the susceptibility of the major EISB faults to reactivation, the slip tendency of the faults has been calculated using the Case 1 parameters given in Table 3 (Figure 11). Slip tendency is the ratio of shear to normal stress, and indicates that slip is likely to occur when the resolved value is equal to, or exceeds the value of $\mu$ (Morris et al. 1996). In the absence of a detailed 3D representation of the faults, they are assumed to be vertical in this analysis, as this is the worst-case scenario given that faults optimally-oriented for failure are vertical under the expected strike-slip stress conditions. The results suggest that many of the fault orientations observed in the EISB exhibit high slip tendency values, including N-S striking faults to the north and west of the East Deemster Fault, where the $S_{\text {Hmax }}$ orientation transitions towards NW-SE (Figure 11). Faults striking perpendicular to $S_{H m a x}$, such as the Lagman Fault, are least likely to become reactivated due to higher normal stresses that inhibit frictional 
sliding, while faults striking parallel or very close to $S_{H \max }$ also exhibit low slip tendency values as they are not subjected to significant shear stresses. While Figure 11 is useful in highlighting the relative tendency of varyingly oriented faults in the EISB to slip, it is important to note that the fault populations in the basin are seldom vertical, dipping instead at relatively low angles (Jackson et al. 1995). The impact of this is that the higher slip tendencies shown in Figure 11 are actually rather conservative, and would likely be reduced if dip was taken into account. Detailed three-dimensional fault models would be required in order to more accurately determine the slip tendency and fault reactivation potential.

In the EISB context, fluid injection such as for natural gas storage or carbon sequestration are likely to be implemented in depleted hydrocarbon fields. Due to coupling between pore pressure and stress it is well known that pressure depletion associated with fluid production from reservoirs can induce changes to the pre-production stresses (Hillis 2000; Zoback \& Zinke 2002). In a pressure-depleted reservoir, fluid pressure increases that could be achieved without reactivating pre-existing faults would likely exceed the 3.3 and $5 \mathrm{MPa}$ calculated for cases 1 and 2 in Figure 9, which were calculated for virgin reservoir conditions. Pressure depletion of the SSG reservoirs in the EISB, of the magnitudes highlighted by Figure 3, may be sufficient to have induced significant changes to the horizontal stresses. It is possible that relative reduction of the horizontal stresses (both $S_{\text {hmin }}$ and $S_{\text {Hmax }}$ ) with respect to the magnitude of $S_{v}$, will have resulted in local changes of the stress regime (transitioning to a normal stress state), if the magnitude of $S_{\text {Hmax }}$ has been reduced sufficiently so that it is now exceeded by the magnitude of $S_{v}$. The magnitude of $S_{v}$ would be expected to have remained unchanged as the earth's surface is a free surface. If the magnitude of $S_{v}$ now locally exceeds the magnitude of $S_{H \text { max }}$, fault orientations optimally-oriented for failure would now be $60^{\circ}$ dipping faults striking parallel to $S_{\text {Hmax }}$. This highlights the necessity of considering the geomechanical impacts of hydrocarbon production as well as fluid injection when planning injection to depleted reservoirs.

\section{Conclusions}

Reactivation of pre-existing faults poses a risk to seal integrity in the EISB. In order to quantify the potential for fault reactivation in the region, the in situ stress tensor has been determined using hydrocarbon well data. Borehole breakouts and drilling-induced tensile fractures suggest a mean $S_{\text {Hmax }}$ orientation of $152^{\circ}$, which is consistent with regional stress orientations. Some variation in the orientation of $S_{\text {Hmax }}$ is noted however, with alignment to major faults suggesting some degree of local structural control. Stress magnitude data suggests the vertical stress exceeds the magnitude of $S_{\text {hmin }}$, signifying that either a strike-slip or normal faulting stress regime is prevalent in the region. On the basis that the onshore UK stress field is predominantly one of strike-slip faulting (Baptie 2010), and that the orientations of $S_{\text {Hmax }}$ observed in the EISB are consistent with those onshore, a strike-slip faulting regime is assumed. This assumption is further supported by the presence of drilling-induced tensile fractures, as relatively high differential stresses are required in order for them to form (Zoback et al. 2003). The magnitude of $S_{H \max }$ has been estimated using frictional faulting limitations, for two different cases assuming variation in frictional fault rock properties.

Regardless of the assumed frictional properties of EISB fault rocks, vertical faults striking $30^{\circ}$ from $S_{\text {Hmax }}\left(182^{\circ}\right.$ or $\left.122^{\circ}\right)$ are most likely to become reactivated under elevated pore pressure conditions. For any project relying on an element of fault seal for the containment of buoyant fluids such as naturallyoccurring hydrocarbons or injected fluids such as natural gas or carbon dioxide, the presence of similarly oriented faults can be considered to enhance the risk of seal-breach or induced-seismicity if present. At the average reservoir depth of $800 \mathrm{~m}$, these optimally-oriented faults will become reactivated if pore pressure increases by 3.3 or $5 \mathrm{MPa}$ depending on the assumed frictional properties, however higher pore pressure increases would be required to initiate reactivation of faults with other orientations. Vertical faults striking perpendicular to $S_{\text {Hmax }}$ would require very high pore pressure perturbations exceeding the minimum principal stress to become reactivated. Seal integrity would then be limited by caprock strength and potentially by capillary-entry pressure. 
Slip tendency analysis has been carried-out for the main faults in the central part of the EISB, and shows that numerous faults striking close to $\mathrm{N}-\mathrm{S}$ have relatively high slip tendency values. This analysis represents the worst-case scenario, where all faults are considered to be vertical. More accurate determination of the slip tendency and susceptibility of the major EISB faults to reactivate is precluded by lack of an accurately constrained 3D representation of the fault network. Furthermore, due to lack of an accurate determination of the $S_{\text {Hmax }}$ magnitude, the differential stress is considered to be at the frictional limit for faults optimally-oriented for failure within the prevailing stress regime. Higher shear stresses are therefore promoted in the slip tendency analysis, and lower pore pressure increases are required to reactivate faults. The analyses presented are therefore inherently conservative, representing the worst-case scenario in terms of fault stability.

The largest natural gas accumulation in the EISB is the South Morecambe Field, which has a column height of $\sim 400 \mathrm{~m}$. Using pressure data from well 110/08a-C1 along with the gas pressure gradient given by Bastin et al. (2003), the pre-production gas column at the field would have exerted a buoyancy overpressure of $\sim 5 \mathrm{MPa}$ at the crest of the field. Such a pressure would have exceeded both the estimated pressure required to reactivate optimally-oriented faults, and the $S_{\text {hmin }}$ magnitude estimated at that depth, but the presence of the significant gas column implies that the overlying MMG and the field-bounding faults do represent effective mechanical seals. The MMG directly over the field is composed of halite, which is likely to possess a fracture pressure greater than the minimum bound to the LOT data estimated in this study. Also, it is unlikely that the field-bounding faults are optimally-oriented for reactivation, despite the high slip tendencies calculated for the southern part of the Tynwald Fault Zone (Figure 11). Seismic sections (Bastin et al. 2003; Knipe et al. 1993) show that the Tynwald Faults and other fieldbounding structures are not vertical as assumed in the slip tendency analysis presented in Figure 11.

In terms of future hydrocarbon exploration in the basin, the mechanical efficacy of the MMG is unlikely to represent a significant risk under contemporary in situ stress conditions, unless significant hydrocarbon accumulations are expected to be discovered with column heights of several hundred metres. Such columns could exert pressure exceeding the $S_{\text {hmin }}$ magnitude at the reservoir-caprock interface if halite is absent or is disrupted by halokinesis. Cenozoic uplift had a significant impact on tertiary hydrocarbon migration in the EISB (Duncan et al. 1998; Cowan et al. 1999), which most likely constitutes the greater exploration risk. For any future gas storage or geological disposal efforts in the EISB (for example of anthropogenic carbon dioxide), operational pressures should be carefully considered in order to mitigate against the potential for fault reactivation and associated risk to storage integrity.

\section{Acknowledgements}

Badley Geoscience Ltd are thanked for the use of their TrapTester software, which was used to generate the stereographic projections, and Schlumberger are thanked for use of Petrel, which was used to generate the slip tendency plot. John Williams, Chris Gent and Mark Fellgett were funded by British Geological Survey National Capability funding from NERC. Davide Gamboa thanks Geo-Carb-Cymru and the Sêr Cymru National Research Network of Low Carbon Energy and Economy for research funding. This paper is published with the permission of the Executive Director, British Geological Survey (NERC).

\section{References}

Aadnoy, B.S. \& Bell, J.S. 1998. Classification of drill-induced fractures and their relationship to insitu stress directions. Log Analyst, 39, 27-42.

Addis, M.A., Hanssen, T.H., Yassir, N., Willoughby, D.R. \& Enever, J. 1998. A Comparison of LeakOff Test And Extended Leak-Off Test Data For Stress Estimation. SPE/ISRM 47235, 131-140. 
Armitage, P.J., Worden, R.H., Faulkner, D.R., Aplin, A.C., Butcher, A.R. \& Espie, A.A. 2013. Mercia Mudstone Formation caprock to carbon capture and storage sites: petrology and petrophysical characteristics. Journal of the Geological Society, 170, 119-132.

Armitage, P.J., Worden, R.H., Faulkner, D.R., Butcher, A.R. \& Espie, A.A. 2015. Permeability of the Mercia Mudstone: suitability as caprock to carbon capture and storage sites. Geofluids, 16, 26-42.

Baker Hughes. 2011. Wellbore Failure Analysis and Geomechanical Modelling in the Bowland Shales, Blackpool, UK. Technical Report conducted on behalf of Cuadrilla Resources. 48pp.

Baptie, B. 2010. Seismogenesis and state of stress in the UK. Tectonophysics, 482 (1-4), 150-159.

Barton, C.A. \& Zoback, M.D. 1988. In-situ stress orientation and magnitude at the Fenton Geothermal Site, New Mexico, determined from wellbore breakouts. Geophysical Research Letters, 15, 467-470.

Barton, C.A., Zoback, M.D. \& Moos, D. 1995. Fluid flow along potentially active faults in crystalline rock. Geology, 23 (8), 683-686.

Bastin, J.C., Boycott-Brown, T., Sims, A. \& Woodhouse, R. 2003. The South Morecambe Gas Field, Blocks 110/2a, 110/3a, 110/7a and 110/8a, East Irish Sea. In: Gluyas, J.G. \& Hichens, H.M. (eds.), United Kingdom Oil and Gas Fields, Commemorative Millennium Volume. Geological Society, London, Memoir, 20, 107-118.

Bell, J.S. 1990. Investigating stress regimes in sedimentary basins using information from oil industry wireline logs and drilling records. In: Hurst, A., Lovell, M.A., Morton, A.C. (eds.), Geological Applications of Wireline Logs. Geological Society, London, Special Publications, 48, 305-325.

Bell, J.S. 1996. In situ stresses in sedimentary rocks (part 2): Applications of stress measurements. Geoscience Canada, 23 (3), 135-153.

Bjørlykke, K., Høeg, K., Faleide, J.I. \& Jahren, J. 2005. When do faults in sedimentary basins leak? Stress and deformation in sedimentary basins; examples from the North Sea and Haltenbanken, offshore Norway. AAPG Bulletin, 89 (8), 1019-1031.

Blundell, D.J. 2002. Cenozoic inversion and uplift of Southern Britain. In: Dóre, A.G., Cartwright, J.A., Stoker, M.S., Turner, J.P. \& White, N. (eds.), Exhumation of the North Atlantic Margin: Timing, Mechanisms and Implications for Petroleum Exploration. Geological Society, London, Special Publications, 196, 85-101.

Breckels, I.M. \& van Eekelen, H.A.M. 1982. Relationship between horizontal stress and depth in sedimentary basins. Journal of Petroleum Technology, 34, 2191-2198.

Bretan, P., Yielding, G., Mathiassen, O.M. \& Thorsnes, T. 2011. Fault-seal analysis for $\mathrm{CO}_{2}$ storage: an example from the troll area, Norwegian Continental Shelf. Petroleum Geoscience, 17,181-192.

Brudy, M. \& Zoback, M.D. 1999. Drilling-induced tensile wall-fractures: implications for determination of in-situ stress orientation and magnitude. International Journal of Rock Mechanics and Mining sciences, 46, 191-215.

Byerlee, J.D. 1978. Friction of rock. Pure and Applied Geophysics, 116, 615-626.

Chadwick, R.A., Kirby, G.A. \& Bailey, H.E. 1994. The post-Triassic structural evolution of north-west England and adjacent parts of the East Irish Sea. Proceedings of the Yorkshire Geological Society, 50, 91-102. 
Chadwick, R.A., Noy, D.J. \& Holloway, S. 2009. Flow processes and pressure evolution in aquifers during the injection of supercritical $\mathrm{CO}_{2}$ as a greenhouse gas mitigation measure. Petroleum Geoscience, 15, 59-73.

Chiaramonte, L., Zoback, M.D., Friedmann, J. \& Stamp, V. 2008. Seal integrity and feasibility of $\mathrm{CO}_{2}$ sequestration in the Teapot Dome EOR pilot: geomechanical characterization. Environmental Geology, 54, 1667-1675.

Clayton, C.J. \& Hay, S.J. 1994. Gas migration mechanisms from accumulation to surface. Bulletin of the Geological Society of Denmark, 41, 12-23.

Colter, V.S. 1997. The East Irish Sea Basin - from caterpillar to butterfly, a thirty-year metamorphosis. In: Meadows, N.S., Trueblood, S.P., Hardman, M. \& Cowan G. (eds.), Petroleum Geology of the Irish Sea and Adjacent Areas. Geological Society, London, Special Publications, 124, 1-9.

Corcoran, D.V. \& Doré, A.G. 2002. Depressurization of hydrocarbon-bearing reservoirs in exhumed basin settings: evidence from Atlantic margin and borderland basins. In: Dóre, A.G., Cartwright, J.A., Stoker, M.S., Turner, J.P. \& White, N. (eds.), Exhumation of the North Atlantic Margin: Timing, Mechanisms and Implications for Petroleum Exploration. Geological Society, London, Special Publications, 196, 457-483.

Cowan, G. 1993. Identification and significance of aeolian deposits within the dominantly fluvial Sherwood Sandstone Group of the East Irish Sea Basin, UK. In: North, C.P. \& Prosser, D.J. (eds.), Characterization of Fluvial and Aeolian Reservoirs. Geological Society, London, Special Publications, 73, 231-245.

Cowan, G. \& Bradney, J. 1997. Regional diagenetic controls on reservoir properties in the Millom accumulation: implications for field development. In: Meadows, N.S., Trueblood, S.P., Hardman, M. \& Cowan, G. (eds.), Petroleum Geology of the Irish Sea and Adjacent Areas. Geological Society, London, Special Publications, 124, 373-386.

Cowan, G., Burley, S.D., Hoey, N., Holloway, P., Bermingham, P., Beveridge, N., Hamborg, M. \& Sylta, Ø. 1999. Oil and gas migration in the Sherwood Sandstone of the East Irish Sea Basin. In: Fleet, A.J. \& Boldy, S.A.R. (eds.), Petroleum Geology of Northwest Europe: Proceedings of the $5^{\text {th }}$ Conference. Geological Society, London, 1383-1398.

Cuss, R.J., Harrington, J.F., Noy, D.J., Sathar, S. \& Norris, S. 2015. An experimental study of the flow of gas along synthetic faults of varying orientation to the stress field: Implications for performance assessment of radioactive waste disposal. Journal of Geophysical Research: Solid Earth. 120, 39323945 .

Dewhurst, D.N., Yang, Y. \& Aplin, A.C. 1999. Permeability and fluid flow in natural mudstones. In: Aplin, A.C., Fleet, A.J. \& Macquaker, J.H.S. (eds.), Muds and Mudstones: Physical and Fluid Flow Properties. Geological Society, London, Special Publications, 158, 23-43.

Duncan, W.I., Green, P.F. \& Duddy, I.R. 1998. Source Rock Burial History and Seal Effectiveness: Key Facets to Understanding Hydrocarbon Exploration Potential in the East and Central Irish Sea Basins. AAPG Bulletin, 82, 1401-1415.

Evans, K.F. 2005. Permeability creation and damage due to massive fluid injections into granite at 3.5 $\mathrm{km}$ at Soultz: 2. Critical stress and fracture strength. Journal of Geophysical Research, 110, B04204.

Evans, D.J. \& Holloway, S. 2009. A review of onshore UK salt deposits and their potential for underground gas storage. In: Evans, D.J. \& Chadwick, R.A. (eds.), Underground Gas Storage: Worldwide Experiences and Future Development in the UK and Europe. Geological Society, London, Special Publications, 313, 39-80. 
Ferrill, D.A., Winterle, J., Wittmeyer, G., Sims, D., Colton, S. \& Armstrong, A. 1999. Stressed Rock Strains Groundwater at Yucca Mountain, Nevada. GSA Today, 9 (5), 1-8.

Ferrill, D.A., Morris, A.P., McGinnis, R.N., Smart, K.J., Wigginton, S.S. \& Hill, N.J. 2017. Mechanical stratigraphy and normal faulting. Journal of Structural Geology, 94, 275-302.

Finkbeiner, T., Zoback, M., Flemings, P. \& Stump, B. 2001. Stress, pore pressure, and dynamically constrained hydrocarbon columns in the South Eugene Island 330 Field, northern Gulf of Mexico. AAPG Bulletin, 85 (6), 1007-1031.

Gölke, M. \& Coblentz, D. 1996. Origins of the European regional stress field. Tectonophysics, 266, 1124.

Haines, S., Marone, C. \& Saffer, D. 2014. Frictional properties of low-angle normal fault gouges and implications for low-angle normal fault slip. Earth and Planetary Science Letters, 408, 57-65.

Heidbach, O., Tingay, M., Barth, A., Reinecker, J., Kurfeß, D. \& Müller, B. 2008. The World Stress Map database release 2008. Doi:10.1594/GFZ.WSM.Rel2008.

Heidbach, O., Tingay, M., Barth, A., Reinecker, J., Kurfeß, D. \& Müller, B. 2010. Global crustal stress pattern based on the World Stress Map database release 2008. Tectonophysics, 482 (1-4), 3-15.

Heidbach, O., Custodio, S., Kingdon, A., Mariucci, M.T., Montone, P., Müller, B., Pierdominici, S., Rajabi, M., Reinecker, J., Reiter, K., Tingay, M., Williams, J. \& Ziegler, M. 2016. Stress Map of the Mediterranean and Central Europe 2016. GFZ Data Service, doi:10.5880/WSM.Europe2016.

Hennings, P., Allwardt, P., Paul, P., Zahm, C., Reid, R. Jr., Alley, H., Kirschner, R., Lee, B. \& Hough, E. 2012. Relationship between fractures, fault zones, stress, and reservoir productivity in the Suban gas field, Sumatra, Indonesia. AAPG Bulletin, 96 (4), 753-772.

Hillis, R.R. 2000. Pore pressure/stress coupling and its implications for seismicity. Exploration Geophysics, 31, 448-454.

Hillis, R.R. \& Nelson, E.J. 2005. In situ stresses in the North Sea and their implications: petroleum geomechanics from exploration to development. In: Dóre, A.G. \& Vining, B.A. (eds.), Petroleum Geology: North-West Europe and Global Perspectives - Proceedings of the $6^{\text {th }}$ Petroleum Geology Conference. Geological Society, London, 551-564.

Hillis, R.R., Holford, S.P., Green, P.F., Doré, A.G., Gatliff, R.W., Stoker, M.S., Thomson, K., Turner, J.P., Underhill, J.R. \& Williams, G.A. 2008. Cenozoic exhumation of the southern British Isles. Geology, 36 (5), 371-374.

Holford, S.P., Turner, J.P. \& Green, P.F. 2005. Reconstructing the Mesozoic-Cenozoic exhumation history of the Irish Sea basin system using apatite fission track analysis and vitrinite reflectance data. In: Dóre, A.G. \& Vining, B.A. (eds.), Petroleum Geology: North-West Europe and Global Perspectives - Proceedings of the $6^{\text {th }}$ Petroleum Geology Conference. Geological Society, London, 1095-1107.

Holford, S.P., Turner, J.P., Green, P.F. \& Hillis, R.R. 2009. Signature of cryptic sedimentary basin inversion revealed by shale compaction data in the Irish Sea, western British Isles. Tectonics, 28, TC4011.

Holford, S.P., Green, P.F., Turner, J.P., Williams, G.A., Hillis, R.R., Tappin, D.R. \& Duddy, I.R. 2008. Evidence for kilometre-scale Neogene exhumation driven by compressional deformation in the Irish Sea basin system. In: Johnson, H., Dóre, A.G., Gatliff, R.W., Holdsworth, R.W., Lundin, E.R. \& Ritchie, J.D. (eds.), The Nature and Origin of Compression in Passive Margins. Geological Society, London, Special Publications, 306, 91-119. 
Holford, S.P., Tassone, D.R., Stoker, M.S. \& Hillis, R.R. 2016. Contemporary stress orientations in the Faroe-Shetland region. Journal of the Geological Society, 173, 142-152.

Jackson, D.I. \& Mulholland, P. 1993. Tectonic and stratigraphic aspects of the East Irish Sea Basin and adjacent areas: contrasts in their post-Carboniferous structural styles. In: Parker, J.R. (Ed.), Petroleum Geology of North-West Europe - Proceedings of the $4^{\text {th }}$ Conference. Geological Society, London, 791808.

Jackson, D.I., Jackson, A.A., Evans, D., Wingfield, R.T.R., Barnes, R.P. \& Arthur. M.J. 1995. The Geology of the Irish Sea. United Kingdom Offshore Regional Report. British Geological Survey and HMSO, London.

Jaeger, J.C., Cook, N.G.W. \& Zimmerman, R. 2007. Fundamentals of Rock Mechanics. Blackwell, Oxford.

Kingdon, A., Fellgett, M.W. \& Williams, J.D.O. 2016. Use of borehole imaging to improve understanding of the in-situ stress orientation of Central and Northern England and its implications for unconventional hydrocarbon resources. Marine and Petroleum Geology, 73, 1-20.

Knipe, R.J., Cowan, G. \& Balendran, V.S. 1993. The tectonic history of the East Irish Sea Basin with reference to the Morecambe Fields. In: Parker, J.R. (Ed.), Petroleum Geology of North-West Europe Proceedings of the $4^{\text {th }}$ Conference. Geological Society, London, 857-866.

Laubach, S.E., Olsen, J.E. \& Gale, J.F.W. 2004. Are open fractures necessarily aligned with maximum horizontal stress? Earth and Planetary Science Letters, 222, 191-195.

Lewis, D., Bentham, M., Cleary, T., Vernon, R., O’Neill, N., Kirk, K., Chadwick, A., Hilditch, D., Michael, K., Allinson, G., Neal, P. \& Ho, M. 2009. Assessment of the potential for geological storage of carbon dioxide in Ireland and Northern Ireland. Energy Procedia, 1, 2655-2662.

Lucier, A., Zoback, M., Gupta, N. \& Ramakrishnan, T.S. 2006. Geomechanical aspects of $\mathrm{CO}_{2}$ sequestration in a deep saline reservoir in the Ohio River Valley region. Environmental Geosciences, 13 (2), 85-103.

Mardia, K.V. 1972. Statistics of Directional Data: Probability and Mathematical Statistics. Academic Press, San Diego, CA.

Mastin, L. 1988. Effect of Borehole Deviation on Breakout Orientations. Journal of Geophysical research: Solid Earth (1978-2012), 90 (B8), 9187-9195.

Meng, L., Fu, X., Lv, Y., Li, X., Cheng, Y., Li, T. \& Jin, Y. 2017. Risking fault reactivation induced by gas injection into depleted reservoirs based on the heterogeneity of geomechanical properties of fault zones. Petroleum Geoscience, 23, 29-38.

Mildren, S.D., Hillis, R.R., Dewhurst, D.N., Lyon, P.J., Meyer, J.J. \& Boult, P.J. 2005. FAST: A new technique for geomechanical assessment of the risk of reactivation-related breach of fault seals. In: Boult, P. \& Kaldi, J. (eds.), Evaluating fault and cap rock seals. AAPG Hedberg Series, 2, 73-85.

Moos, D. \& Zoback, M.D. 1990. Utilization of observations of well bore failure to constrain the orientation and magnitude of crustal stresses: application to continental, Deep Sea Drilling Project, and Ocean Drilling Program boreholes. Journal of Geophysical Research, 95, 9305-9325.

Morris, A., Ferrill, D.A. \& Henderson, D.B. 1996. Slip-tendency analysis and fault reactivation. Geology, 24 (3), 275-278. 
Müller, B., Zoback, M.L., Fuchs, K., Mastin, L., Gregersen, S., Pavoni, N., Stephansson, O. \& Ljunggren, C. 1992. Regional patterns of tectonic stress in Europe. Journal of Geophysical Research, 97 (B8), 11783-11803.

Needham, T.I.M. \& Morgan, R. 1997. The East Irish Sea and adjacent basins: new faults or old? Journal of the Geological Society, 154, 145-150.

Pharaoh, T.C., Smith, N.J.P., Kirk, K., Kimbell, G.S., Gent, C., Quinn, M. \& Monaghan, A.A. 2016. Palaeozoic Petroleum Systems of the Irish Sea. British Geological Survey, Commissioned Report, CR/16/045. 135pp. http://nora.nerc.ac.uk/516794/

Pharaoh, T.C., Gent, C.M.A., Hannis, S.D., Kirk, K.L., Monaghan, A.A., Quinn, M.F., Smith, N.J.P., Vane, C.H., Wakefield, O. \& Waters, C.N. (in press). An overlooked play? Structure, stratigraphy and hydrocarbon prospectivity of the Carboniferous in the East Irish Sea - North Channel Basin complex. In: Monaghan, A.A., Underhill, J.R., Marshall, J.E.A. \& Hewett, A. (eds.), Palaeozoic Plays of NW Europe. Geological Society, London, Special Publications, 465.

Quirk, D.G., Roy, S., Knott, I., Redfern, J. \& Hill, L. 1999. Petroleum geology and future hydrocarbon potential of the Irish Sea. Journal of Petroleum Geology, 22 (3), 243-260.

Reynolds, S., Hillis, R. \& Paraschivoiu, E. 2003. In situ stress field, fault reactivation and seal integrity in the Bight Basin, South Australia. Exploration Geophysics, 34, 174-181.

Rowley, E. \& White, N. 1998. Inverse modelling of extension and denudation in the East Irish Sea and surrounding areas. Earth and Planetary Science Letters, 161, 57-71.

Sathar, S., Reeves, H.J., Cuss, R.J. \& Harrington, J.F. 2012. The role of stress history on the flow of fluids through fractures. Mineralogical Magazine, 76 (8), 3165-3177.

Seedhouse, J.K. \& Racey, A. 1997. Sealing capacity of the Mercia Mudstone Group in the East Irish Sea Basin: Implications for petroleum exploration. Journal of Petroleum Geology, 20, 261-286.

Sibson, R.H. 1994. Crustal stress, faulting and fluid-flow. In: Parnell, J. (ed.), Geofluids: Origin, Migration and Evolution of Fluids in Sedimentary Basins, 78, 69-84.

Spain, J.D. \& Conrad, C.P. 1997. Quantitative analysis of top-seal capacity: offshore Netherlands, Southern North Sea. Geologie en Mijnbouw, 76 (3), 217-226.

Sperner, B., Müller, B., Heidbach, O., Delvaux, D., Reinecker, J. \& Fuchs, K. 2003. Tectonic stress in the Earth's crust: advances in the World Stress Map project. In: Nieuwland, D.A. (ed.), New Insights into Structural Interpretation and Modelling. Geological Society, London, Special Publications, 212, $101-116$.

Stuart, I.A. 1993. The geology of the North Morecambe Gas Field, East Irish Sea Basin. In: Parker, J.R. (Ed.), Petroleum Geology of North-West Europe - Proceedings of the $4^{\text {th }}$ Conference. Geological Society, London, 883-895.

Stuart, I.A. \& Cowan, G. 1991. The South Morecambe Field, Blocks 110/2a, 110/3a, 110/8a, UK East Irish Sea. In: Abbots, I.L. (ed.), United Kingdom Oil and Gas Fields, 25 Years Commemorative Volume. Geological Society, London, Memoir, 14, 527-541.

Swarbrick, R.E. \& Osborne, M.J. 1998. Mechanisms that generate abnormal pressures: an overview. In: Law, B.E., Ulmishek, G.F. \& Slavin, V.I. (eds.), Abnormal pressures in hydrocarbon environments. AAPG Memoir, 70, 13-34.

Tingay, M., Muller, B., Reinecker, J., Heidbach, O., Wenzel, F. \& Fleckenstein, P. 2005. Understanding tectonic stress in the oil patch: The World Stress Map Project. The Leading Edge, 24 (12), 1276-1282. 
Turner, J.P. 1997. Strike-slip fault reactivation in the Cardigan Bay basin. Journal of the Geological Society, 154, 5-8.

Ware, P.D. \& Turner, J.P. 2002. Sonic velocity analysis of the Tertiary denudation of the Irish Sea basin. In: Dóre, A.G., Cartwright, J.A., Stoker, M.S., Turner, J.P. \& White, N. (eds.), Exhumation of the North Atlantic Margin: Timing, Mechanisms and Implications for Petroleum Exploration. Geological Society, London, Special Publications, 196, 355-370.

White, A.J., Traugott, M.O. \& Swarbrick, R.E. 2002. The use of leak-off tests as means of predicting minimum in-situ stress. Petroleum Geoscience, 8, 189-193.

Williams, G.A., Turner, J.P. \& Holford, S.P. 2005. Inversion and exhumation of the St. George's Channel Basin, offshore Wales, UK. Journal of the Geological Society, 162, 97-110.

Williams, J.D.O., Holloway, S. \& Williams, G.A. 2014. Pressure constraints on the $\mathrm{CO}_{2}$ storage capacity of the saline water-bearing parts of the Bunter Sandstone Formation in the UK Southern North Sea. Petroleum Geoscience, 20, 155-167.

Williams, J.D.O., Fellgett, M.W., Kingdon, A. \& Williamson, J.P. 2015. In-situ stress orientations in the UK Southern North Sea: Regional trends, deviations and detachment of the post-Zechstein stress field. Marine and Petroleum Geology, 67, 769-784.

Williams, J.D.O., Fellgett, M.W. \& Quinn, M.F. 2016. Carbon dioxide storage in the Captain Sandstone aquifer: determination of in situ stresses and fault-stability analysis. Petroleum Geoscience, 22, 211222.

Wilson, A.A. 1990. The Mercia Mudstone Group (Trias) of the East Irish Sea Basin. Proceedings of the Yorkshire Geological Society, 48, 1-22.

Wiprut, D. \& Zoback, M.D. 2000. Fault reactivation and fluid flow along a previously dormant normal fault in the northern North Sea. Geology, 28 (7), 595-598.

Zoback, M.D., Moos, L.G., Mastin, L.G. \& Anderson, R.N. 1985. Well bore breakouts and in situ stress. Journal of Geophysical Research, 90, 5523-5530.

Zoback, M.D. \& Zinke, J.C. 2002. Production-induced Normal Faulting in the Valhall and Ekofisk Oil Fields. Pure and Applied Geophysics, 159, 403-420.

Zoback, M.D., Barton, C.A., Brudy, M., Castillo, D.A., Finkbeiner, T., Grollimund, B.R., Moos, D.B., Peska, P., Ward, C.D. \& Wiprut, D.J. 2003. Determination of stress orientation and magnitude in deep wells. International Journal of Rock Mechanics and Mining Sciences, 40, 1049-1076. 


\begin{tabular}{lccccccccc}
\hline Well & $\begin{array}{c}\text { Log } \\
\text { Type }\end{array}$ & $\begin{array}{c}\text { Number } \\
\text { of } \\
\text { Indicators }\end{array}$ & $\begin{array}{c}\text { Stress } \\
\text { Indicat } \\
\text { or } \\
\text { Type }\end{array}$ & $\begin{array}{c}\text { Top } \\
\text { Depth } \\
(\mathrm{m} \mathrm{ss})\end{array}$ & $\begin{array}{c}\text { Bottom } \\
\text { Depth } \\
(\mathrm{m} \mathrm{ss})\end{array}$ & $\begin{array}{c}\text { Total } \\
\text { Length } \\
(\mathrm{m})\end{array}$ & $\begin{array}{c}\text { Mean } S_{H \max } \\
\text { orientation } \\
\left({ }^{\circ}\right)\end{array}$ & $\begin{array}{c}\text { Standard } \\
\text { Deviation } \\
\left({ }^{\circ}\right)\end{array}$ & $\begin{array}{c}\text { WSM } \\
\text { Rank }\end{array}$ \\
\hline $109 / 05-1$ & FMS & 7 & BO & 801.4 & 839.7 & 8.84 & 154.49 & 4.53 & $\mathrm{D}$ \\
$110 / 04-1$ & UBI & 2 & BO & 552.6 & 560.8 & 5.94 & 161.66 & 2.84 & $\mathrm{D}$ \\
$110 / 08 \mathrm{a}-5$ & FMI & 1 & BO & 1294.6 & 1295.6 & 0.9 & 160.05 & - & $\mathrm{D}$ \\
$110 / 14-3$ & FMS & 1 & BO & 1236.8 & 1237.6 & 0.76 & 181.3 & - & $\mathrm{D}$ \\
$111 / 15-1$ & FMS & 3 & BO & 1575.4 & 1590.5 & 7.96 & 141.22 & 1.15 & $\mathrm{D}$ \\
$113 / 27 b-6$ & FMI & 2 & DITF & 1419.3 & 1452.3 & 3.72 & 133.84 & 4.42 & D \\
\hline Summary & - & 16 & - & - & - & 24.42 & 152.23 & 12.13 & - \\
\hline
\end{tabular}

Table 1. Summary of borehole stress indicators used to define $S_{\text {Hmax }}$ orientation in the EISB. $S_{\text {Hmax }}$ orientation and number weighted standard deviation calculated using the circular statistics of Mardia (1972). BO=Breakout, DITF=Drilling-Induced Tensile Fracture, ss=sub-sea.

\begin{tabular}{|c|c|c|c|c|c|c|c|c|c|}
\hline Well & $\begin{array}{l}\text { Log } \\
\text { Type }\end{array}$ & $\begin{array}{c}\text { Number } \\
\text { of } \\
\text { Indicators }\end{array}$ & $\begin{array}{c}\text { Stress } \\
\text { Indicat } \\
\text { or } \\
\text { Type } \\
\end{array}$ & $\begin{array}{c}\text { Top } \\
\text { Depth } \\
\text { (m ss) }\end{array}$ & $\begin{array}{l}\text { Bottom } \\
\text { Depth } \\
\text { (m ss) }\end{array}$ & $\begin{array}{l}\text { Total } \\
\text { Length } \\
\text { (m) }\end{array}$ & $\begin{array}{c}\text { Mean } S_{\text {Hmax }} \\
\text { orientation } \\
\left(^{\circ}\right)\end{array}$ & $\begin{array}{c}\text { Standard } \\
\text { Deviation } \\
\left(^{\circ}\right)\end{array}$ & $\begin{array}{l}\text { WSM } \\
\text { Rank }\end{array}$ \\
\hline Doe Green 3 & FMI & 8 & $\mathrm{BO}$ & 462.8 & 1221.8 & 9.4 & 151.99 & 6.82 & $\mathrm{D}$ \\
\hline Ince Marshes & FMI & 129 & $\begin{array}{l}\text { BO / } \\
\text { DITF }\end{array}$ & 403.3 & 1416.64 & 211.7 & 164.98 & 10 & A \\
\hline Preese Hall & CMI & - & $\begin{array}{l}\text { BO / } \\
\text { DITF }\end{array}$ & - & - & - & 173 & 7 & - \\
\hline
\end{tabular}

Table 2. Summary of borehole stress indicators used to define $S_{H \max }$ orientation in onshore region bounding the EISB. Data for Preese Hall are taken from Baker Hughes (2011); image logs were not re-interpreted as part of this study. Doe Green 3 is a deviated borehole with 43 BO and DITF observations, however only those observations where borehole deviation $<10$ degrees from vertical are presented here following Mastin (1988).

\begin{tabular}{lccccccc}
\hline & $\begin{array}{c}\text { Pore } \\
\text { Pressure } \\
(\mathrm{MPa})\end{array}$ & $S v(\mathrm{MPa})$ & $\begin{array}{c}S_{\text {hmin }} \\
(\mathrm{MPa})\end{array}$ & $\begin{array}{c}S_{\text {Hmax }} \\
\text { orientation }\end{array}$ & $C(\mathrm{MPa})$ & $\mu$ & $\begin{array}{c}\text { Upper bound } \\
S_{\text {Hmax }}(\mathrm{MPa})\end{array}$ \\
\hline Case 1 & 9.3 & 17.9 & 14.4 & $152.23^{\circ}$ & 2 & 0.6 & 25.23 \\
Case 2 & 9.3 & 17.9 & 14.4 & $152.23^{\circ}$ & 2 & 0.4 & 20.44 \\
\hline
\end{tabular}

Table 3. Parameters used to model fault reactivation and seal integrity in the EISB, for a depth of $800 \mathrm{~m}$ below mean sea level. The two cases account for uncertainty regarding the coefficient of friction $(\mu)$ of optimally-oriented faults. 


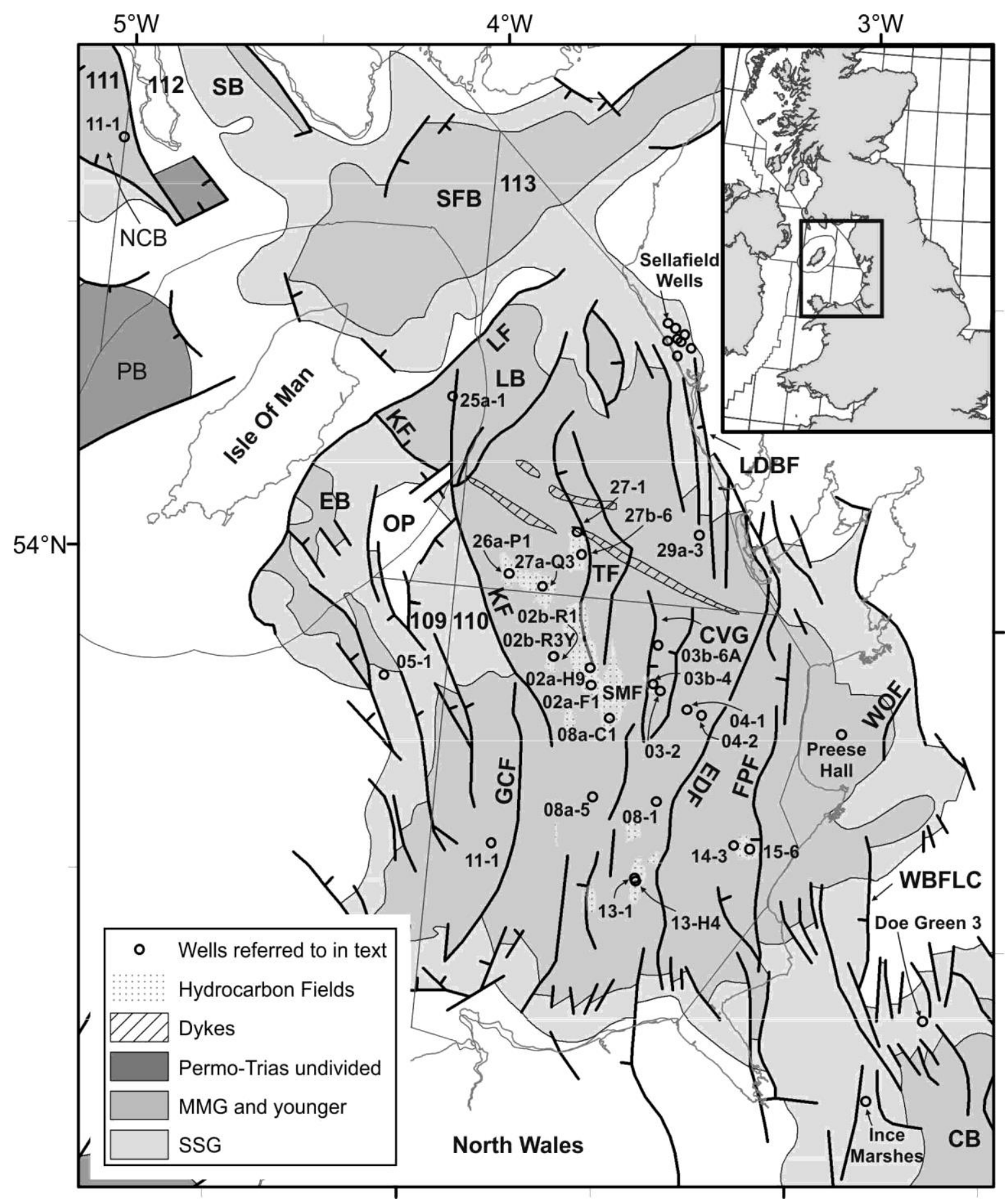

Fig. 1. Location of EISB and surrounding basins, main structural features and distribution of Sherwood Sandstone and Mercia Mudstone Groups (after Jackson et al. 1995), hydrocarbon fields, and key wells. Well names are preceded by UK offshore quadrant numbers (shown by bold labels in quadrant corners). CB, Cheshire Basin; CVG, Crosh Vusta Graben; EB, Eubonia Basin; EDF, East Deemster Fault; FPF, Formby Point Fault; GCF, Godred Croven Fault; KB, Keys Basin; KF, Keys Fault; LB, Lagman Basin; LDBF, Lake District Boundary Fault; LF, Lagman Fault; NCB, North Channel Basin; OP, Ogham Platform; PB, Peel Basin; SB, Stranraer Basin; SFB, Solway Firth Basin; SMF, South Morecambe Gas Field; TF, Tynwald Fault Zone; WBFLC, Western Boundary Fault of the Lancashire Coalfield; WOF, Woodsford Fault. Coastline, fields and quadrant data contain public sector information licenced under the Open Government Licence v3.0. 


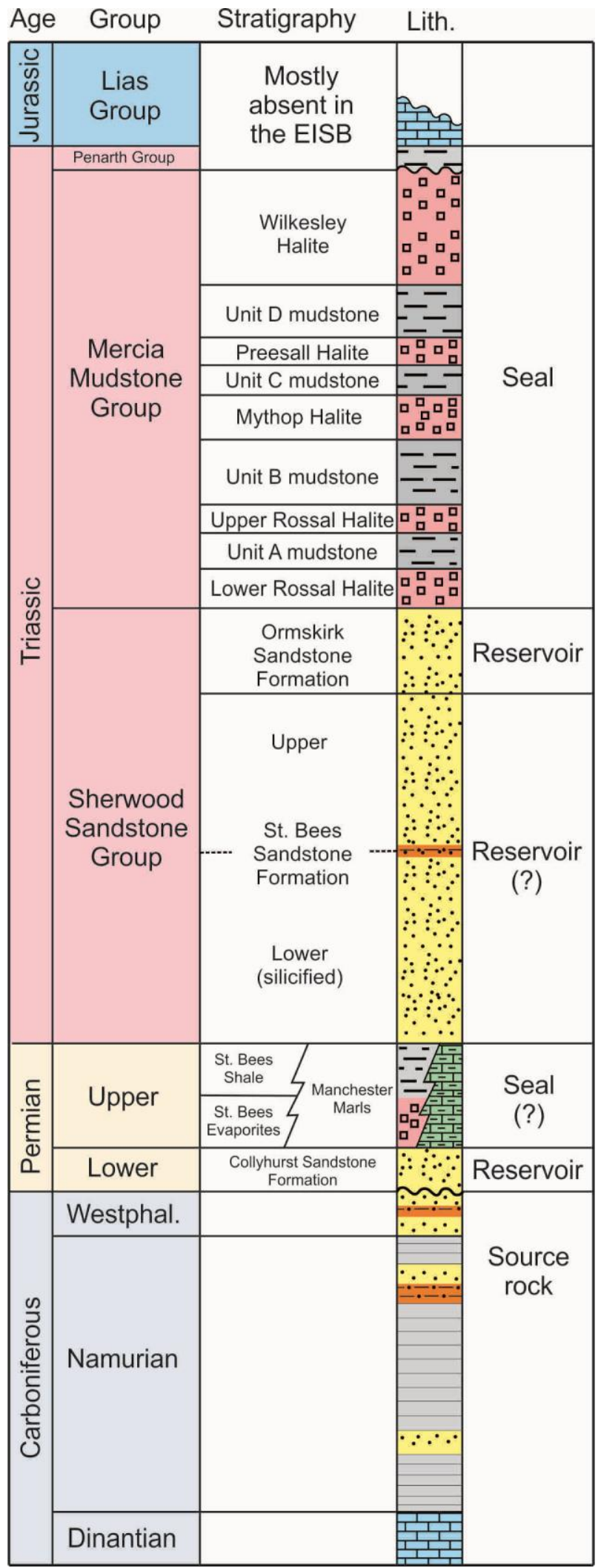

Fig. 2. Schematic stratigraphic column for the East Irish Sea showing broad stratigraphic, lithological and petroleum system relationships. Stratigraphic nomenclature after Jackson et al. (1995). 


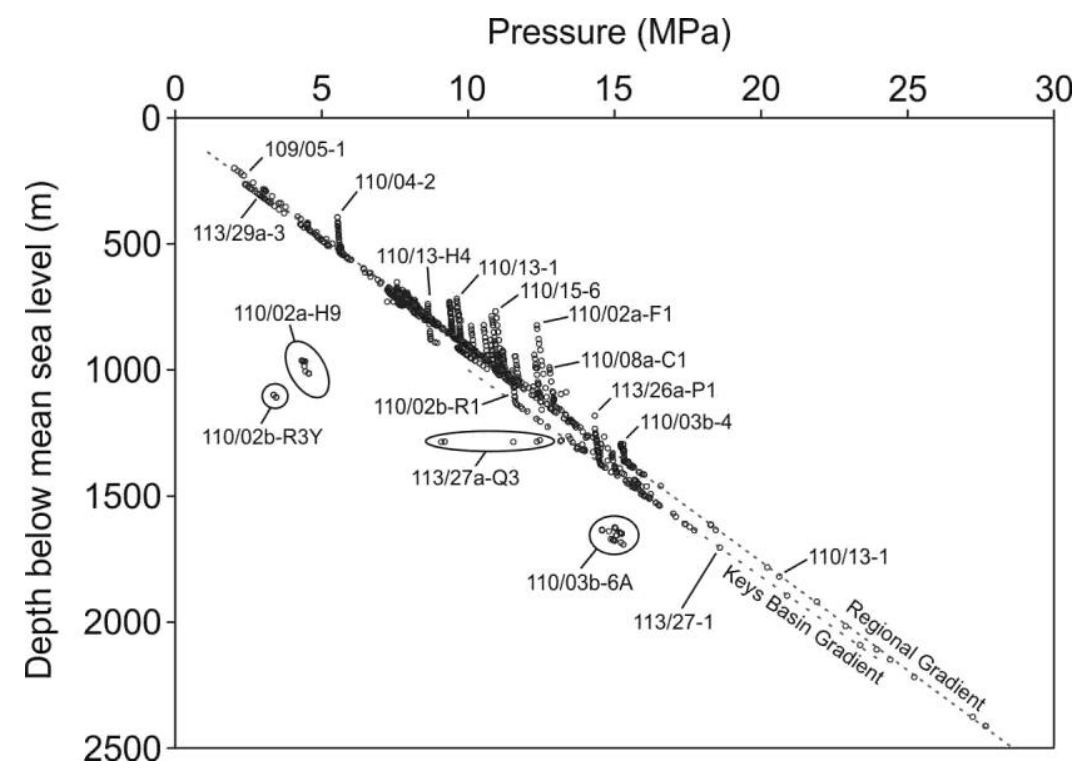

Fig. 3. Pore pressure data from the EISB showing pore pressure gradients for the EISB as a whole and for the Keys Basin (dotted lines). Pressure data that indicate hydrocarbon columns for certain wells are labelled, and data from wells displaying considerable depletion due to hydrocarbon production are also highlighted. Wells referred to in text are labelled along with significant outliers.

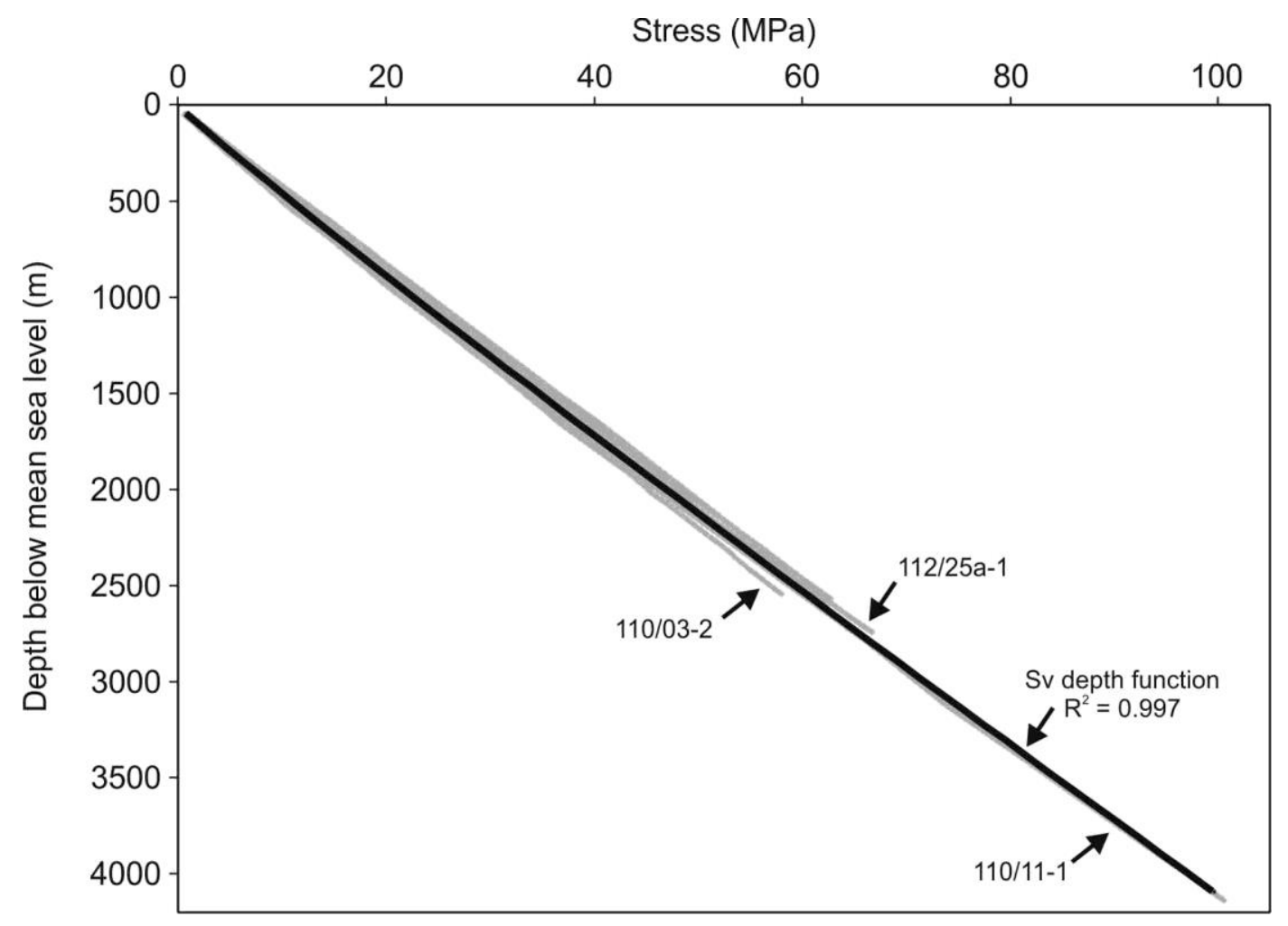

Fig. 4. Vertical stress magnitudes for 35 wells in the East Irish Sea Basin along with $S_{v}$ depth function (solid black line). The deepest well from which the vertical stress has been estimated, is 110/10-1, which extends into the Namurian. 


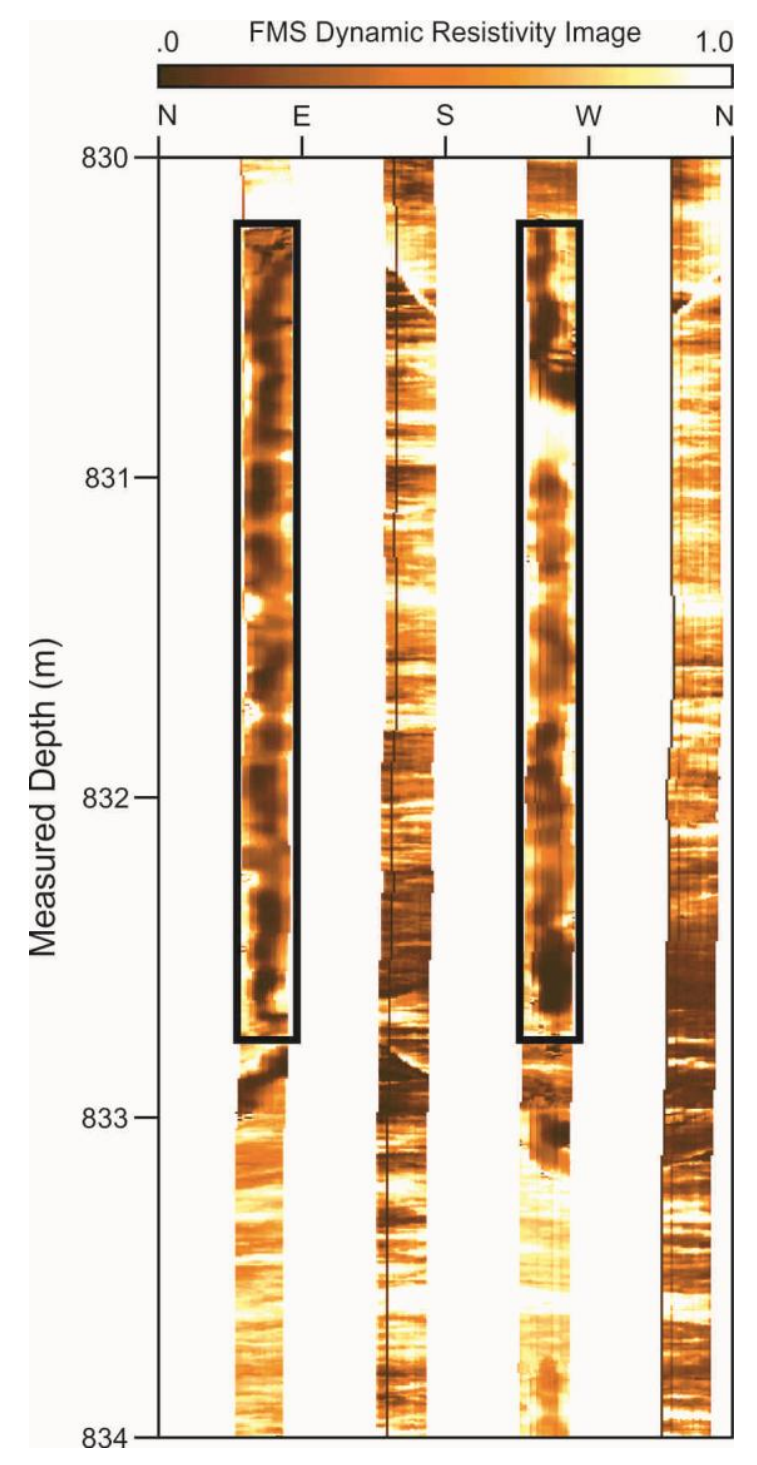

Fig. 5. Unwrapped circumferential (clockwise from north) resistivity borehole image (FMS) from well 109/05-1, showing typical example of borehole breakout observed in the EISB. The breakout zone is highlighted by the black boxes on opposing sides of the borehole wall and is oriented ENE-WSW, indicating $S_{\text {Hmax }}$ orientation of NNW-SSE. 


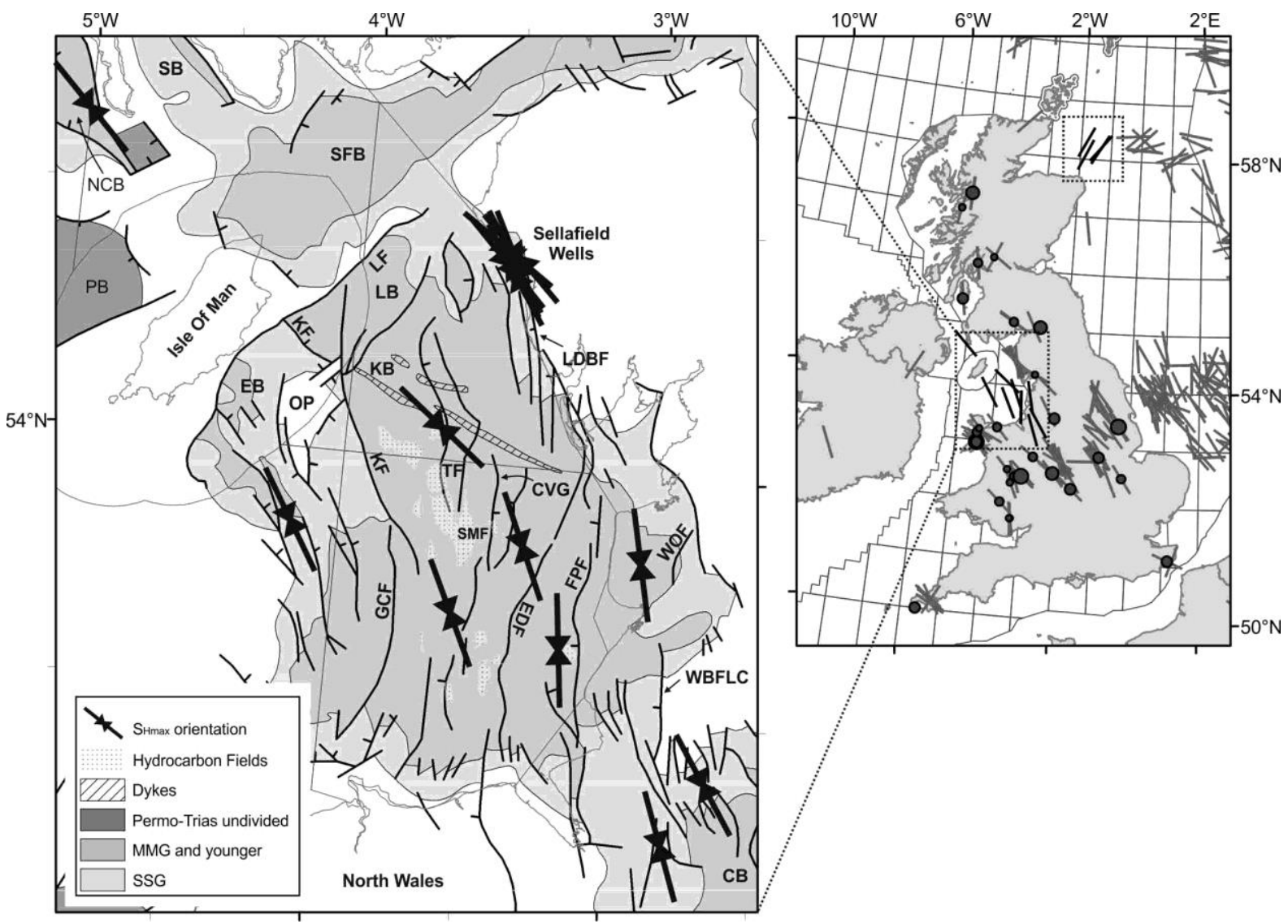

Fig. 6. $S_{\text {Hmax }}$ orientations in the EISB and adjacent regions. Stress orientations of Sellafield wells taken from Kingdon et al. (2016) and structural features as denoted in Figure 1. Inset map places new data into regional context showing quality A-D $S_{\text {Hmax }}$ orientations from WSM as grey markers (Heidbach $e t$ al. 2016) and recently published data from the Inner Moray Firth within stippled box (Williams et al. 2016). Location of earthquake focal mechanisms used by Baptie (2010) shown by graduated circles (Magnitudes 2.8-5.4). Coastline, fields and quadrant data contain public sector information licenced under the Open Government Licence v3.0. 


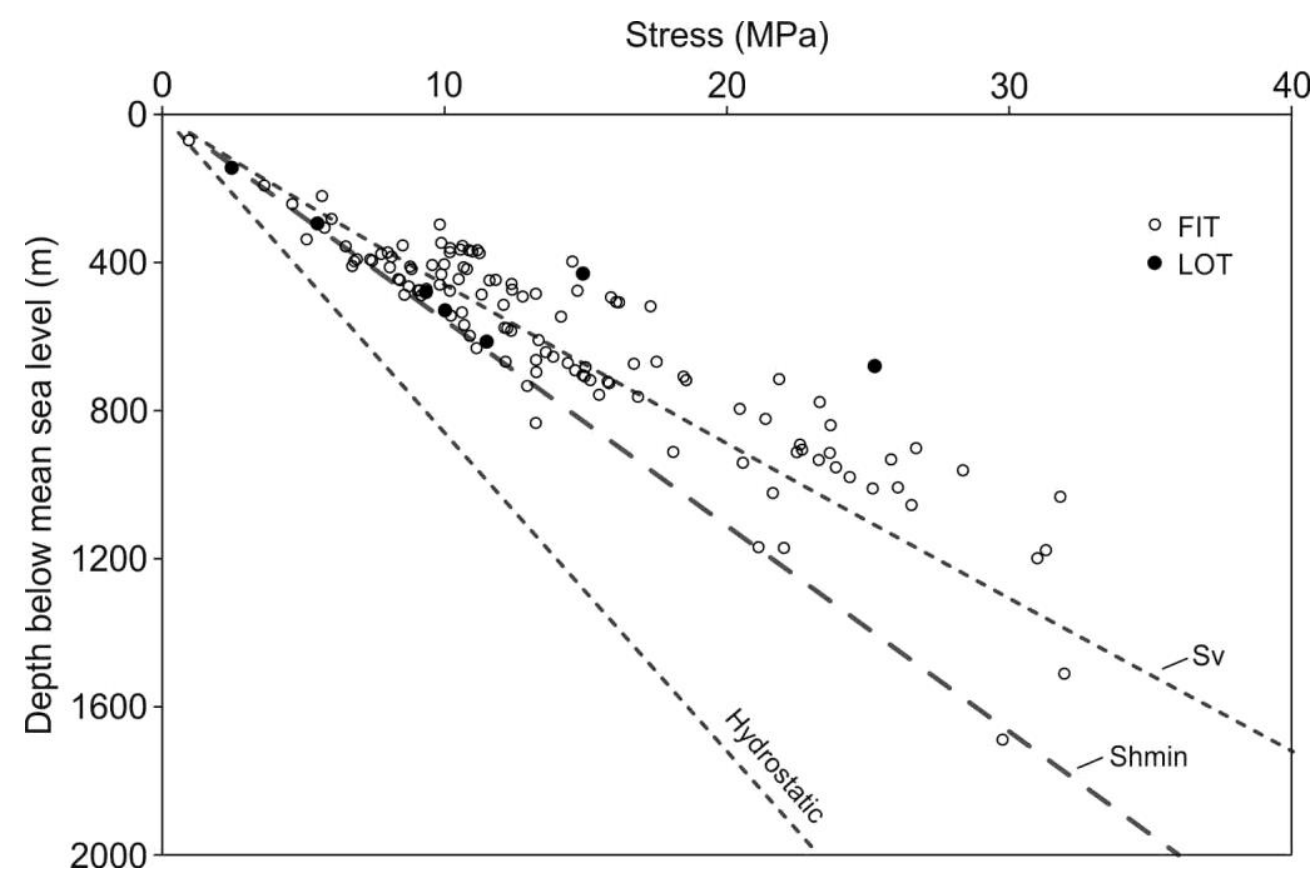

Fig. 7. Formation Leak-Off Test (LOT) and Formation Integrity test (FIT) data from the EISB relative to a regional hydrostatic gradient of $11.628 \mathrm{MPa} / \mathrm{km}$, vertical stress $\left(S_{v}\right)$ function (equation 3 ) and lowerbound LOT gradient $\left(S_{\text {hmin }}\right)$ of $18 \mathrm{MPa} / \mathrm{km}$.

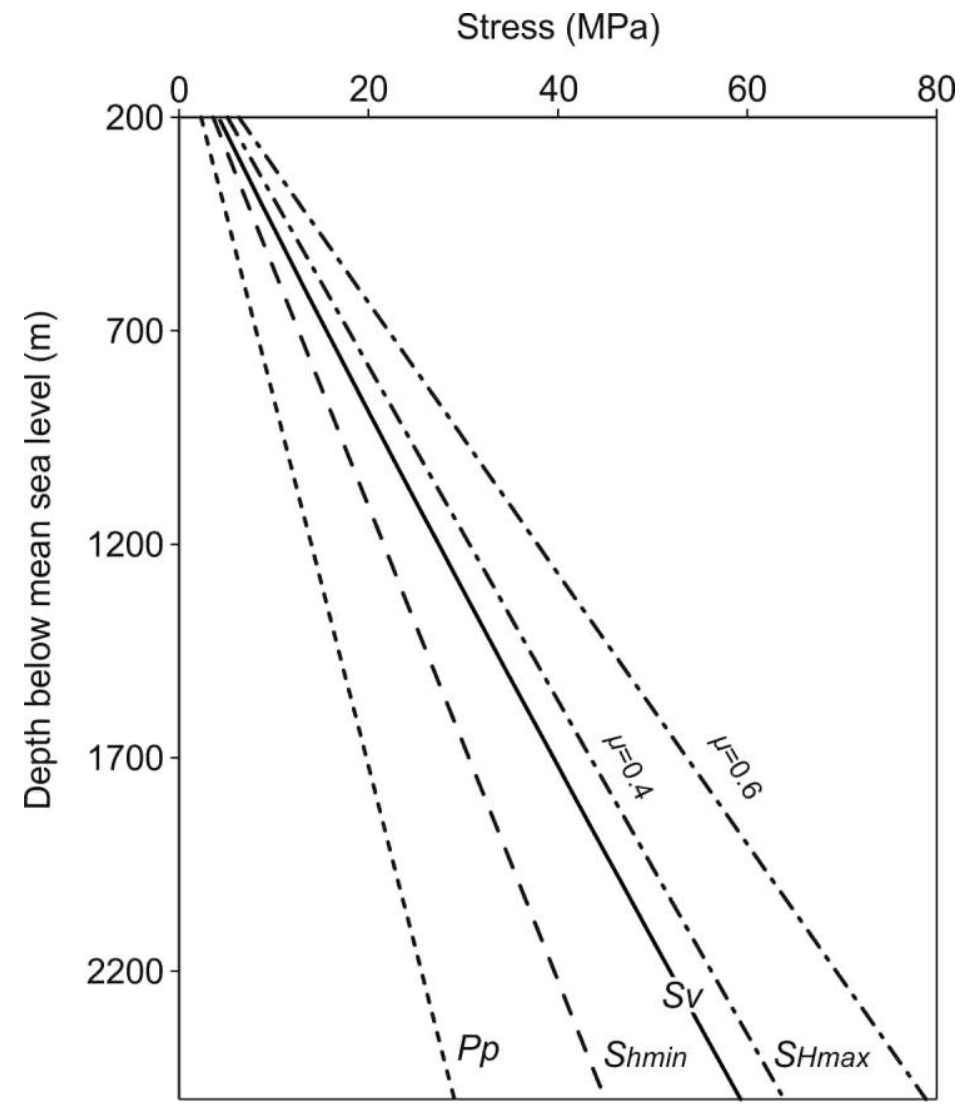

Fig. 8. Regional in situ stress-depth plot for the EISB. Pore pressure is taken from the regional pore pressure gradient, $S_{\text {hmin }}$ represents the lower bound to LOT measurements, $S v$ is calculated using the power law function described by equation 3, and two cases are assumed for $S_{H \max }$, estimated using frictional limits based on different friction coefficients $(\mu)$ for optimally-oriented faults. 


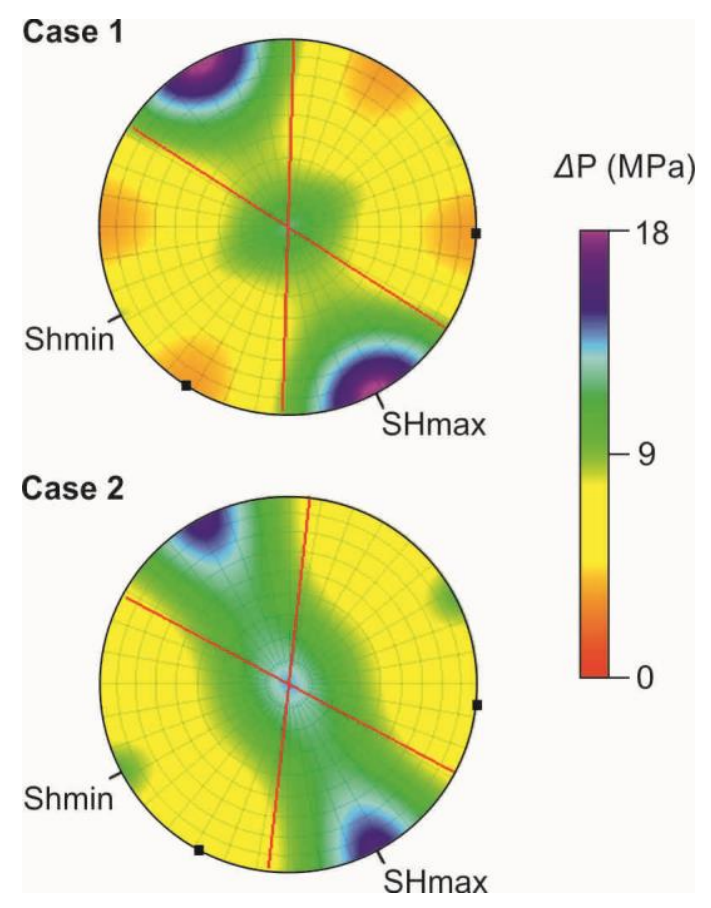

Fig. 9. Equal angle, lower hemisphere stereographic projections of poles to planes, displaying risk of fault reactivation at a depth of $800 \mathrm{~m}$ in the EISB for two cases with differing coefficients of friction (Table 3). The numerical values refer to the increase in fluid pressure $(\Delta P)$ required to cause fault reactivation, assuming a Griffith-Coulomb failure envelope with stress state and failure envelope parameters from Table 3. The black poles to planes and strike lines indicate the orientations of optimally-oriented faults.
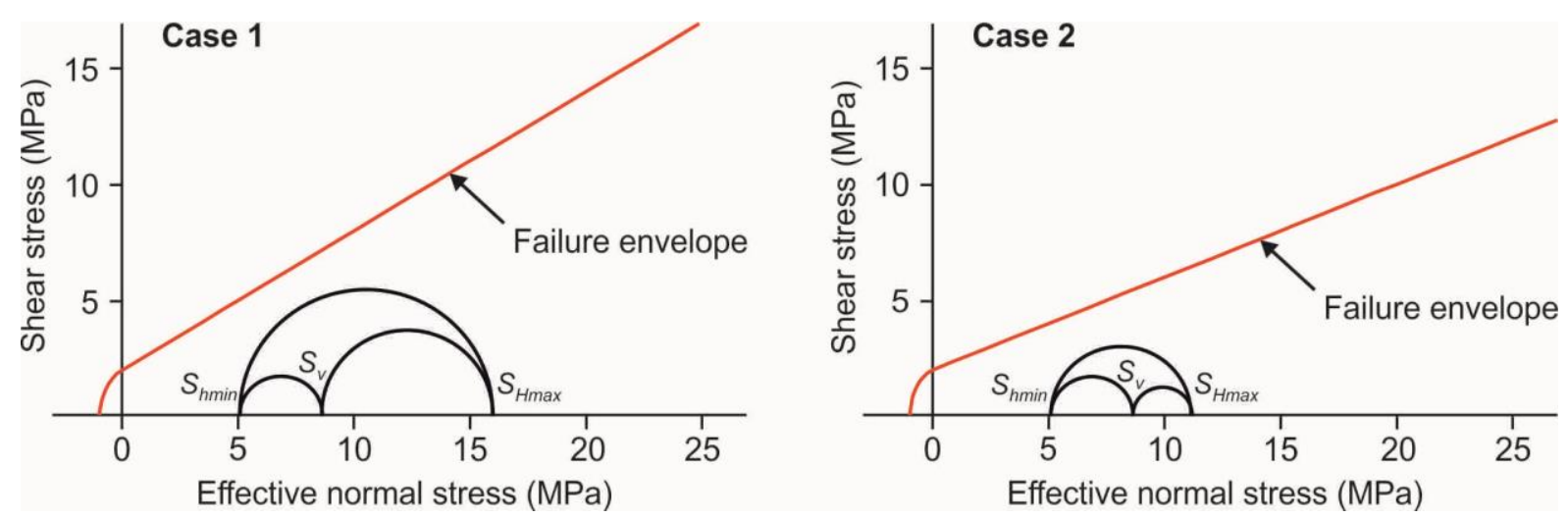

Fig. 10. Mohr circle representation of EISB stress state at $800 \mathrm{~m}$ depth using stress-field parameters and assumed failure envelope shown in Table 3. Despite the lower angle of the Case 2 failure envelope, the differential stress is lower because of the frictional limit placed on the magnitude of $S_{\text {Hmax }}$. Case 2 therefore has a greater horizontal distance from the failure envelope, and greater $\Delta P$ would be required to initiate failure. 


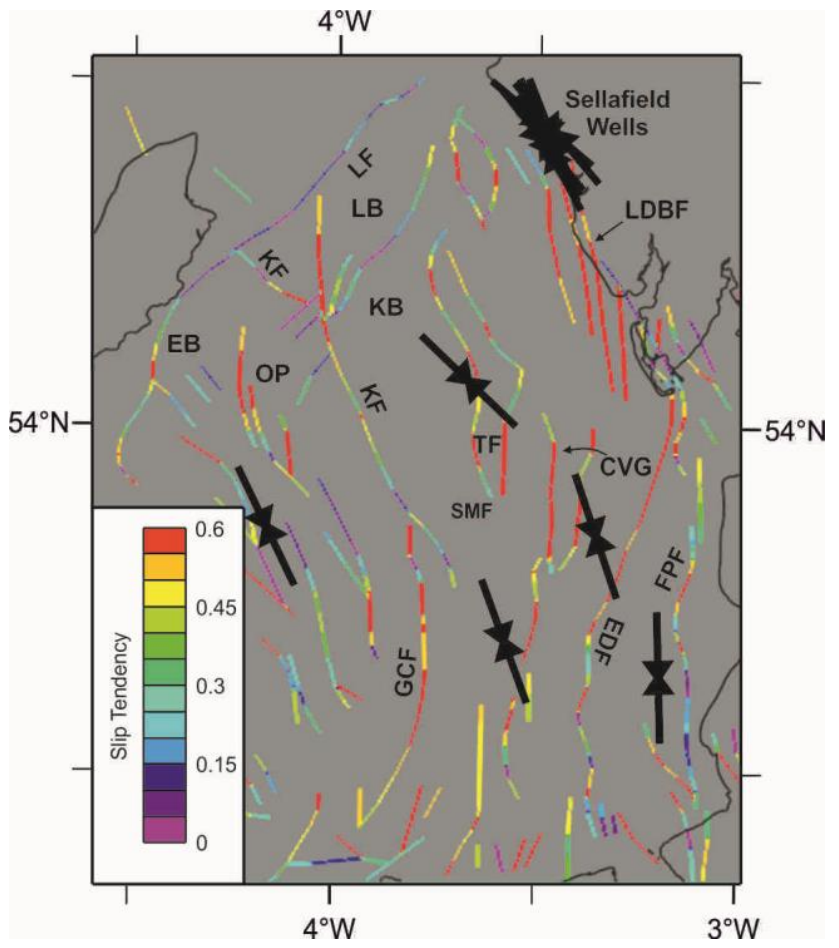

Fig. 11. Slip tendency of faults across the central part of the EISB, accounting for variation in orientation of $S_{\text {Hmax }}$, but assuming that all faults are vertical. The orientation of $S_{\text {Hmax }}$ is assumed to vary smoothly between the borehole stress indicators. Structural features as denoted in Figure 1. 